\title{
Formation of Southern Hemisphere Thermocline Waters: Water Mass Conversion and Subduction*
}

\author{
JOHANNES KARSTENSEN ${ }^{+}$ \\ Lamont-Doherty Earth Observatory of Columbia University, Palisades, New York \\ DeTLEF QuADFASEL \\ Niels Bohr Institutet for Astronomi, Fysik og Geofysik, Geofysisk Afdeling og Center for Jordens Klima og Biogeokemiske Kredsløb, \\ Kobenhavns Universitet, Copenhagen, Denmark
}

(Manuscript received 3 April 2001, in final form 19 March 2002)

ABSTRACT

The ventilation of the permanent thermocline of the Southern Hemisphere gyres is quantified using climatological and synoptic observational data. Ventilation is estimated with three independent methods: the kinematic method provides subduction rates from the vertical and horizontal fluxes through the base of the mixed layer, the water age uses in situ age distribution of thermocline waters, and the annual-mean water mass formation through air-sea interaction is calculated. All three independent estimates agree within their error bars, which are admittedly large. The subduction rates are mainly controlled through their vertical and lateral components with only minor transient eddy contributions. The vertical transfer, derived from Ekman pumping, ventilates over most of the areas of the subtropical gyres, while lateral transfer occurs mainly along the Subtropical and Subantarctic Fronts, where it injects mode and intermediate waters. For the permanent thermocline the overall ventilation of the South Atlantic is about $21 \mathrm{~Sv}\left(\mathrm{~Sv} \equiv 10^{6} \mathrm{~m}^{3} \mathrm{~s}^{-1}\right)$. Of this, lateral transfer contributes $10 \mathrm{~Sv}$, mainly in the Brazil-Malvinas confluence zone and to the northeast of Drake Passage. The effective vertical transfer at the bottom of the mixed layer is only two-thirds of the Ekman pumping due to strong northward forcing of the mixed layer itself. The Indian Ocean is ventilated at a rate of $35 \mathrm{~Sv}$ with equal lateral and vertical contributions. The South Pacific's overall ventilation is $44 \mathrm{~Sv}$ of which the lateral input contributes little more than half. West of $130^{\circ} \mathrm{W}$, the South Pacific is ventilated through Ekman pumping and with only minor lateral transfer. In the east lateral transfer dominates between $10^{\circ}$ and $20^{\circ} \mathrm{S}$ and along the Subantarctic Front in a narrow density range. Combining overall transports with earlier estimates for the Northern Hemisphere gives a ventilation of the World Ocean's permanent thermocline of about $160 \mathrm{~Sv}$. Analysis of atmospheric reanalysis air-sea flux data reveals an overall increase in the formation of thermocline waters for all three Southern Hemisphere oceans.

\section{Introduction}

Buoyancy forcing at high latitudes leads to convection, which feeds and renews the deep waters of the oceans at a rate of approximately $30 \mathrm{~Sv}\left(\mathrm{~Sv} \equiv 10^{6}\right.$ $\mathrm{m}^{3} \mathrm{~s}^{-1}$ ). This drives the global thermohaline circulation, which is associated with timescales of centuries or longer (Broecker and Peng 1982). The intermediate layers of the ocean, composing of permanent thermocline, are, in contrast, wind-driven and their renewal timescales are much shorter, of order decades. Their ventilation

\footnotetext{
* Lamont-Doherty Earth Observatory Contribution Number 6336.

+ Current affiliation: Programa Regional de Oceanografía Fisica y Clima, Universidad de Concepcion, Concepcion, Chile.
}

Corresponding author address: Johannes Karstensen, Programa Regional de Oceanografía Fisica y Clima (PROFC), Universidad de Concepcion, Casilla 160-C, Concepcion-3, Chile.

E-mail: j.karstensen@omnet.com rates, however, appear to be much larger than those of the deep waters and have been estimated to lie around 20-30 Sv for each of the two subtropical gyres of the Northern Hemisphere (Marshall et al. 1993; Qiu and Huang 1995) and for the South Pacific (Huang and Qiu 1998) and South Indian Ocean (Karstensen and Quadfasel 2002). The deep and the intermediate depth circulation regimes interact in the Southern Ocean (Schmitz 1996; Marshall 1997; Marsh et al. 2000; Speer et al. 2000; Sloyan and Rintoul, 2001a,b). Here, upwelling of deep waters and intense air-sea interaction (heat, freshwater, and momentum fluxes) convert deep water into thermocline and intermediate waters that subsequently participate in the wind-driven circulation and eventually return to the sites of deep convection (Talley 1999).

Montgomery (1938) and Iselin (1939) described the first conceptual models of thermocline ventilation. They explained the similarity between vertical interior and meridional surface stratification through sinking and 
spreading from the surface into the interior along isopycnal surfaces. A consequence of the poleward temperature and salinity decrease is an almost linear temperature and salinity relationship of the water. Sverdrup et al. (1942) defined a first comprehensive set of thermocline water masses for the world oceans, which they named "central waters." McCartney $(1977,1982)$ inspected the Southern Hemisphere thermocline waters in more detail and found vertically homogenous layers (thermostads) within the central waters, which he called Subantarctic Mode Water following Masuzawa's (1969) introduction of the term "mode water" to describe the thick layer of temperature $16^{\circ}-18^{\circ} \mathrm{C}$ in the northwestern North Pacific, on the southern side of the Kuroshio Extension. The thermostads form through convective overturn and contribute considerably to the ventilation of all subtropical gyres.

Ekman pumping in regions of negative wind stress curl and horizontal advection through the tilted mixed layer base are mechanisms driving water from the surface mixed layer into the stratified interior (Stommel 1979; Luyten et al. 1983; Woods 1985; Cushman-Roisin 1987; Nurser and Marshall 1991). More recently the transfer of water through mesoscale eddies has entered the discussion (Tandon and Garrett 1996; Marshall 1997). Garabato et al. (2001) found eddy-driven subduction rates of order of $20 \mathrm{~m} \mathrm{yr}^{-1}$ along the Antarctic Polar Front, which they consider to be representative for all Southern Ocean fronts. These rates are of the same order as the mean subduction. Over the Southern Ocean the westerly wind field drives a northward Ekman transport that forces upwelling of water in the south supplied by southward geostrophic flow at depth. This overturning is called the Deacon cell. As a result isopycnals slope steeply and partly outcrop in the south. The high potential energy of the system is partly released through baroclinic instabilities into mesoscale eddies. This can be interpreted as a bolus velocity-driven meridional circulation counteracting the Deacon cell (e.g., Speer et al. 2000) driving upper-layer water poleward across the fronts. The subsurface return flow toward the equator may contribute to the ventilation of the thermocline; however, little is known about the meridional and vertical structure of the circulation cells, their strength, and how they interact.

The pumping of mixed layer waters into the thermocline through the curl of the wind stress creates central waters. These are the water masses covered by the classical Luyten et al. (1983) theory of the ventilated thermocline. Mode water transfer is different and can also be seen in regions with annual Ekman suction rather than pumping. The formation is out of a homogenized layer, produced through intense air-sea interaction, which subsequently is laterally driven through the tilted mixed layer. The densest mode waters feed the intermediate waters in the North Atlantic and the Southern Ocean. A recent review by Hanawa and Talley (2001) summarizes present knowledge about mode water formation and distribution.

Two methods are commonly used to calculate subduction rates from observational data. One is based on analyzing the vertical velocity field derived from Ekman layer dynamics, the horizontal geostrophic velocity field, and the mixed layer topography using climatological hydrographic data (Marshall et al. 1993; Qiu and Huang 1995). From climatological data the eddy component cannot be resolved as long as the eddies are not stationary. The second method to calculate the subduction rates is based on "water ages" obtained from transient tracer data such as chlorofluorocarbons (CFCs) or helium/tritium (Jenkins 1987; Williams et al. 1995). This method includes the contribution of eddies to the subduction rates as it analyzes the subduction rates of individual water parcels (Karstensen and Quadfasel 2002).

Some attempts have been made to quantify thermocline ventilation through subduction for the Southern Hemisphere oceans, but none of them covered all three oceans simultaneously and used the different methods in parallel. Huang and Qiu (1998) analyzed climatological data and estimated the subduction into the South Pacific Ocean gyre using a kinematic approach. In contrast to this study they employed a pseudo-Lagrangian reference frame. They found the thermocline to be mainly ventilated through vertical input (18 Sv) with only a minor contribution from lateral input ( $4 \mathrm{~Sv}$ ). Weak mode water formation was found related to the separation of the western boundary current, the East Australian Current. However, their analysis did not cover the whole density range of the ventilated region. Karstensen and Quadfasel (2002) calculated subduction rates for the south Indian Ocean. They found a transport of $34 \mathrm{~Sv}$ with about equal contributions from lateral and vertical components. The lateral input dominated for densities larger than $25.2 \mathrm{~kg} \mathrm{~m}^{-3}$ and covered several mode waters (McCartney 1977, 1982; Fine 1993). Our estimates of the subduction in the southern Indian Ocean given here are essentially the same (35 vs $34 \mathrm{~Sv}$ ) as in Karstensen and Quadfasel (2002). The small difference can be attributed to the different wind stress climatology used, which has an effect on the Ekman pumping contribution.

Using an inverse model, Sloyan and Rintoul (2001a) found a conversion of Antarctic surface water from airsea interaction over the Southern Ocean of $35 \mathrm{~Sv}$ and estimated the overall northward transport in the mode/ intermediate water range to $80 \mathrm{~Sv}$. They found 22, 31, and $25 \mathrm{~Sv}$ of northward transport in the layer 26.0-27.4 $\mathrm{kg} \mathrm{m}^{-3}$ for the South Atlantic, Indian, and Pacific Oceans, respectively. Marsh et al. (2000) analyzed water mass formation in the Southern Ocean using a noneddy-resolving model with an active mixed layer, a parameterized bolus velocity, and seasonally varying surface forcing. For the mode water density range 25.28$27.38 \mathrm{~kg} \mathrm{~m}^{-3}$ water mass formation of about 15,25 , 
and $24 \mathrm{~Sv}$ were found for the South Atlantic, south Indian, and South Pacific Oceans, respectively. Ribbe and Tomczak (1997) investigated the influence of the northward drift of surface waters from the Antarctic Circumpolar Current (ACC) in the formation regions of mode and intermediate waters using model simulations. They found cross-frontal mixing to play a vital role in the formation, whereas England et al. (1993) in their model results saw no evidence for an Antarctic contribution to the formation of mode waters. Speer et al. (1997) deduced the formation of water masses from climatological surface flux data. For the South Atlantic the thermocline water formation was about $17 \mathrm{~Sv}$; in the south Indian Ocean, they found a rate of about 25 Sv. In the South Pacific Ocean about $15 \mathrm{~Sv}$ of central water and $8 \mathrm{~Sv}$ of intermediate water are formed. Earlier investigations (e.g., Speer et al. 1995) excluded the Southern Ocean because of the uncertainties in the surface flux fields caused by sparse observational data.

Recently, decadal-scale variability of the water mass characteristics and their formation in the Southern Hemisphere oceans were investigated using synoptic observational data (Bindoff and Church 1992; Bindoff and McDougall 2000; Johnson and Orsi 1997; Wong et al. 1999) as well as climate models (Banks et al. 2000). The studies show that the mode waters have warmed and intermediate water has freshened over the past 10 20 years and that their overall production has increased. Using a coupled atmosphere-ocean model without flux adjustments, Banks et al. (2000) simulated changes in thermocline water formation in the southern Indian Ocean in response to anthropogenic changes in atmospheric greenhouse gas concentrations. They claim that the increase of the freshwater content in Southern Ocean waters is responsible for a decline of the subduction rates of intermediate water and thereby confirm the study of Wong et al. (1999). In contrast, Levitus et al. (2000) found a warming of the upper 1000-m water column in all three oceans although they did not conclude on the freshwater signal as no long-term salinity measurements are available.

In this paper we give a comprehensive and uniform circumpolar analysis of water mass formation and subduction for the Southern Hemisphere permanent thermocline based on climatological and synoptic observational data. Exchange windows between the Southern Ocean and the subtropical gyres are investigated. We employ the kinematic approach on climatological data and quantify the formation of Southern Hemisphere waters in terms of vertical central water and lateral mode/ intermediate water ventilation. Error estimates for different choices of mixed layer depth criteria, reference level for the geostrophic calculation, and the wind field are given. We compare the combined ventilation rates with those obtained from the water age approach using tracer data from WOCE (World Ocean Circulation Experiment) to assess the contribution of transient eddies to the subduction. Also a comparison with water mass formation rates as deduced from surface density fluxes is made. Here we examine the overall change in water mass formation rates using reanalysis data from an atmospheric model.

\section{Subduction rate}

\section{a. Kinematic approach}

The instantaneous subduction rate $S$ is defined as the downward velocity of a fluid parcel relative to the base of the mixed layer (Woods 1985; Cushman-Roisin 1987):

$$
S=-\partial h / \partial t-w_{h}-\mathbf{u}_{h} \cdot \nabla h .
$$

Here $h$ is the depth of the mixed layer base, $\mathbf{u}_{h}$ is the horizontal (lateral) velocity of a parcel at the base of the mixed layer, $w_{h}$ is the vertical velocity at the base of the mixed layer, and $t$ is the time. Subduction can occur year round and is dominated by the vertical movements of the base of the mixed layer (order of $1000 \mathrm{~m}$ $\mathrm{yr}^{-1}$ in spring and $500 \mathrm{~m} \mathrm{yr}^{-1}$ in autumn and winter). However, over the course of the year the first term, describing the time rate of change, vanishes if no longterm change in mixed layer properties is present (Marshall et al. 1993). Hence the latter two terms compose the annual mean subduction rate.

The vertical component $w_{h}$ in (1) is calculated from the curl of the wind stress field $(T)$ and subsequently corrected for its contribution to the meridional Sverdrup transport contained in the mixed layer (Williams 1991):

$$
w_{h}=\frac{1}{\rho} \operatorname{curl}\left(\frac{T}{f}\right)-\frac{\beta}{f} \int_{-h}^{0} v d z .
$$

Here $\rho$ is the density of seawater, $v$ is the meridonal velocity, $f$ is the planetary vorticity, and $\beta$ is its meridional gradient. The lateral component $\left(\mathbf{u}_{h} \cdot \nabla h\right)$ in (1) is calculated from the horizontal geostrophic velocity at the deepest mixed layer $\left(\mathbf{u}_{h}\right)$ considering the inclined base of the deepest mixed layer $(\boldsymbol{\nabla} h)$. An important idea in this approach is that the winter climatology is representative for the short time window of irretrievable subduction (Stommel 1979). Qiu and Huang (1995) calculated annual three-dimensional flow trajectories out of a pseudo-Lagrangian flow field derived from climatological data. They traced individual parcels in greater detail analyzing subduction (transfer into the interior) and obduction (return transfer into the mixed layer) and compared their results with the kinematic approach applied here. Over most of the regions, annualmean subduction rates coincide, while in the narrow frontal regions they found up to about $30 \%$ lower values. They attributed these to the different structure of the control surface between mixed layer and thermocline used in the two approaches. 
(a)

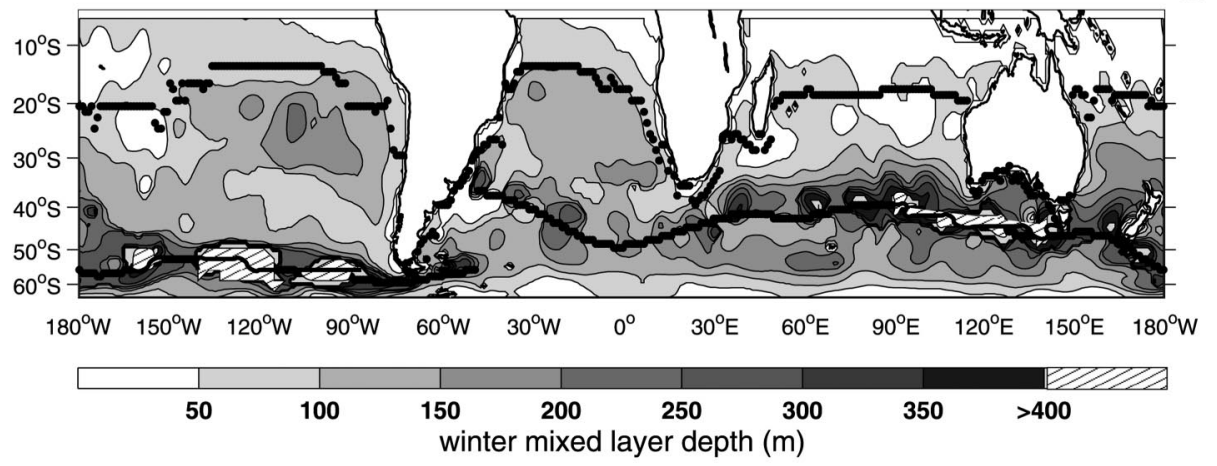

(b)

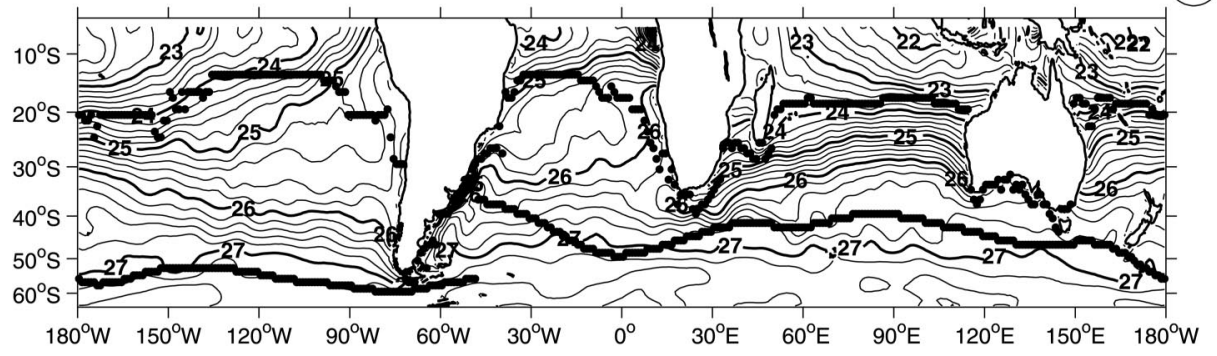

FIG. 1. (a) Depth and (b) density anomaly of the deepest mixed layer depth as calculated from the WOA data using the $0.125 \mathrm{~kg} \mathrm{~m}^{-3}$ criterion. The ventilated region (bounded by black dotted line) lies between the trough of the deepest mixed layer in the south and by the line of zero vertical velocity at the base of the deepest mixed layer in the north (see text for details). Density anomaly contours are in $0.1 \mathrm{~kg} \mathrm{~m}^{-3}$, labels in $1 \mathrm{~kg} \mathrm{~m}^{-3}$ steps.

\section{1) MiXED LAYER DEPTHS AND OUTCROP REGION}

The mixed layer seasonality and the topography of its base during late winter play a key role in the subduction process and in setting the characteristics of the waters ventilating the thermocline (Stommel 1979; Woods 1985). Water irretrievably entering the thermocline originates from the deepest mixed layer, usually in late winter/early spring. Subduction occurs also during the rest of the year, but the subducted parcels are always overtaken by the deepening mixed layer during the cooling season and do not directly contribute to the ventilation.

Different criteria may be used to calculate the mixed layer depth, such as surface referenced temperature or density changes. Here we use the depth of a certain density increase of $0.075,0.125$, and $0.200 \mathrm{~kg} \mathrm{~m}^{-3}$, respectively. The World Ocean Atlas 1998 (WOA: Levitus and Boyer 1994; Levitus et al. 1994) Southern Hemisphere winter temperature and annual-mean salinity data were used to calculate densities and mixed layer depths (Fig. 1). For salinity seasonal changes are generally small in the depth range considered, allowing one to use the annual mean rather than seasonal or monthly resolved data.

The general structure of the deepest mixed layer at the southern rim of the subtropical gyre is zonal (Mc-
Cartney 1977, 1982; England et al. 1993). The trough follows the northern flank of the Circumpolar Current and is located south of the Subtropical Front (Orsi et al. 1995). The mixed layer deepens between the western Atlantic and the eastern Pacific from $200 \mathrm{~m}$ to more than $700 \mathrm{~m}$, but this depth increase is not gradual. Superimposed on the trend are oscillations with wavelengths of 1000-2000 km. Topographic ridges causing the currents to deviate from their zonal path may be responsible for these irregularities, but some may also be due to poor data coverage leading to a bumpy climatology. We will come back to this problem later when discussing the lateral component of the subduction.

Because we are interested in the ventilation of the permanent thermocline, its outcrop region has to be determined. Often the wind stress curl is used as an approximation of the vertical component of the subduction rate. However, the lateral component may allow water to be subducted even if the wind stress curl does not support subduction. We use the very deep winter mixed layer trough in the south as a guide. It acts as a natural boundary between the subtropical gyres and the Southern Ocean. Water subducted farther south has to pass this region to reach the interior of the Southern Hemisphere gyres and it will become again part of the mixed layer during its way north. Contributions from south of 
the trough may thus be ignored for the direct gyre ventilation (Fig. 1). At the equatorward side of the subtropical gyres the ventilation of the interior is mainly controlled through the vertical component of subduction. Ekman pumping is greatly reduced in the nearequatorial region, due to the wind forcing of the mixed layer. Therefore we use the northernmost influence of the vertical component as northernmost boundary of the subduction domain (Fig. 2b). Since the line of zero vertical flux is rather noisy, we used a smoothed version for our calculations. The spatial structure of the deepest mixed layer and its boundaries is not sensitive to the choice of mixed layer definition, but the mean depths change by about $\pm 25 \%$ using either the $0.075 \mathrm{~kg} \mathrm{~m}^{-3}$ or $0.200 \mathrm{~kg} \mathrm{~m}^{-3}$ criterion as compared with the 0.125 $\mathrm{kg} \mathrm{m}^{-3}$ criterion.

The South Atlantic has a broad outcrop area between $15^{\circ} \mathrm{S}$ and $35^{\circ}-45^{\circ} \mathrm{S}$, covering the whole of the subtropical gyre (Fig. 1). Outcrop densities here reach $27.1 \mathrm{~kg}$ $\mathrm{m}^{-3}$ in the southeast. A second smaller region of outcrop lies northeast of Drake Passage and is associated with the northward turn of the ACC. Outcrop densities here are between 27.0 and $27.3 \mathrm{~kg} \mathrm{~m}^{-3}$ and are thus in the range of Antarctic Intermediate Water. These dense waters originate in the Pacific Ocean and should be considered as part of the Pacific Ocean water masses. In the south Indian Ocean the outcrop of the subtropical gyre is confined between $20^{\circ}$ and $40^{\circ} \mathrm{S}$, but reaches $45^{\circ} \mathrm{S}$ south of Australia. Maximum outcrop density is 26.9 $\mathrm{kg} \mathrm{m}^{-3}$. The southerly location of the tropical outcrop boundary in this sector is due to the extent of the monsoon wind field that reaches across the equator and forces the doldrums to lie around $8^{\circ} \mathrm{S}$ rather than north of the equator as in the Pacific and Atlantic Oceans. South of Africa the mixed layer trough bifurcates and a second shallow trough appears farther south between the Subantarctic and Polar Fronts (Orsi et al. 1995). It is associated with densities of up to $27.3 \mathrm{~kg} \mathrm{~m}^{-3}$ and thus in the intermediate water range. In the South Pacific the subduction region widens again and reaches northward to about $15^{\circ} \mathrm{S}$ in the east. Here, between $20^{\circ}$ and $30^{\circ} \mathrm{S}$ a broad region of deep mixed layers can be seen centered near $110^{\circ} \mathrm{W}$. A strong southward bend of the poleward boundary is seen near New Zealand, but the highest latitude of $60^{\circ} \mathrm{S}$ is reached in Drake Passage. Here the outcrop region continues into the Atlantic Ocean. The South Pacific has the highest outcrop densities of up to $27.3 \mathrm{~kg} \mathrm{~m}^{-3}$ and the deepest mixed layer in a region between $140^{\circ}$ and $120^{\circ} \mathrm{W}$ where all southern oceans fronts merge due to the topographic steering of the ACC (Orsi et al. 1995).

\section{2) THE VerticAl COMPONENT}

The vertical transfer of water from the mixed layer into the thermocline is controlled by the wind-induced Ekman pumping velocity (Luyten et al. 1983). This velocity can be calculated directly from the curl of the wind stress, but has to be corrected for the contribution of the Ekman pumping to the meridional Sverdrup transport within the mixed layer. We tried three different wind climatologies for the calculation of the Ekman pumping: the original Hellerman and Rosenstein wind stress climatology (Hellerman and Rosenstein 1983), the $20 \%$ reduced version of this dataset that compensates for a bias in the drag coefficient calculations (Josey et al. 2002), and the Southampton Oceanography Centre (SOC) global air-sea heat and momentum flux climatology (SOC: Josey et al. 1999). The reduced Hellerman and Rosenstein (1983) and the SOC climatology give similar results in the south Indian and South Atlantic Ocean, but in the South Pacific Ekman pumping velocities in the northern part of the outcrop region are higher by about $50 \%$ when using SOC. Because SOC is based on more recent data (1980 to 1993) than Hellerman and Rosenstein (1983) (1870 to 1976) and uses corrections for observational biases and parametrizations (Josey et al. 2002) such as a revised drag coefficient, we decided to use it as our reference.

The annual mean Ekman pumping velocities over the ventilated regions lie between 25 and $100 \mathrm{~m} \mathrm{yr}^{-1}$ in all three oceans (Fig. 2a). In all oceans bands of stronger downwelling stretch from northwest to southeast. Ekman pumping is much reduced in the southern outcrop regions, at least in the Atlantic and the Pacific.

To derive $w_{h}$ [Eq. (2)] the annual-mean average geostrophic velocity within the mixed layer based on WOA data is used (discussed below; Fig. 2c). In the South Atlantic and Pacific Oceans strong meridional transports in the mixed layer reduce the Ekman induced subduction by about $30 \%$ compared to the vertical Ekman pumping at the surface, while in the Indian Ocean the reduction is only $20 \%$ (Table 1 ). Using either of the two Hellerman and Rosenstein (1983) climatologies changes the effective vertical component of the subduction by about $20 \%$, as expected.

\section{3) THE HORIZONTAL COMPONENT}

The velocity field at the base of the deepest mixed layer was calculated from the thermal wind relation using annual mean temperature and salinity data from WOA. A reference level at 2000 dbar or at the seafloor in shallower regions was used. To estimate uncertainties associated with this choice of the reference depth we repeated the calculations with levels of 1750 and 2500 $\mathrm{m}$. These are arbitrary, but reflect the depth interval used in more detailed calculations of the subtropical gyres circulation (e.g., Stramma and Peterson 1990; Stramma 1992; Stramma et al. 1995; Stramma and England 1999). They are too shallow to capture the magnitude of the ACC velocity field correctly, which has in addition a significant barotropic component. However, this does not upset our subduction calculations as these are largely limited to regions north of the ACC. This is confirmed through the low sensitivity of only $10 \%$ of 

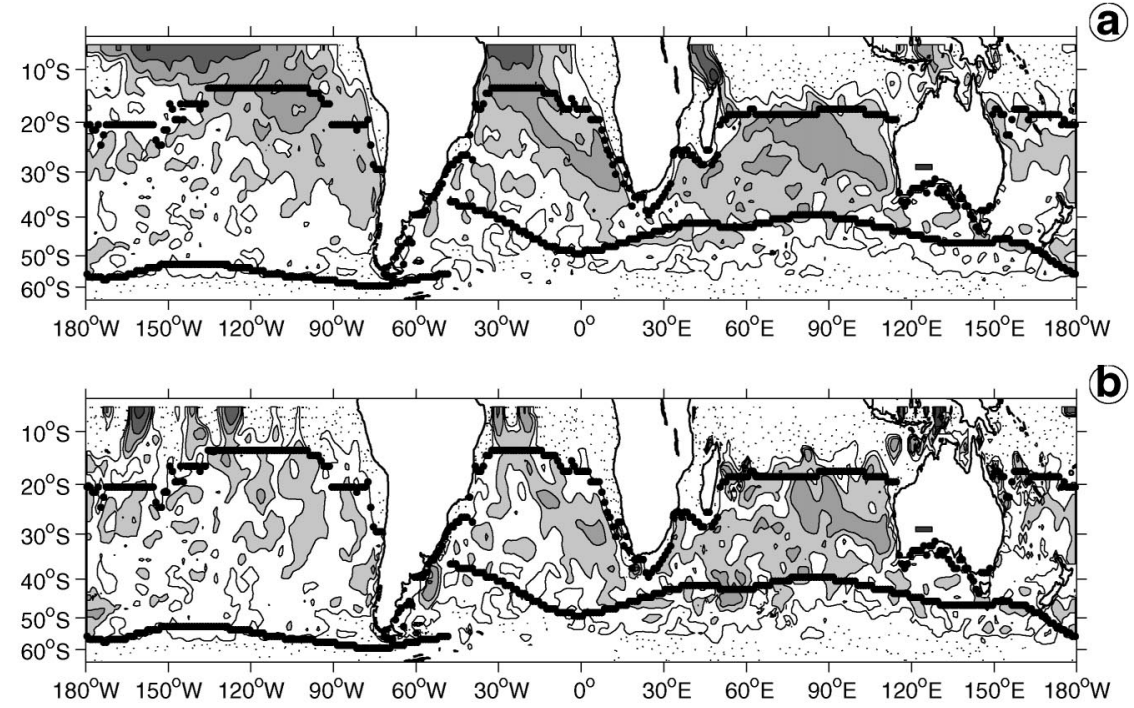

(b)
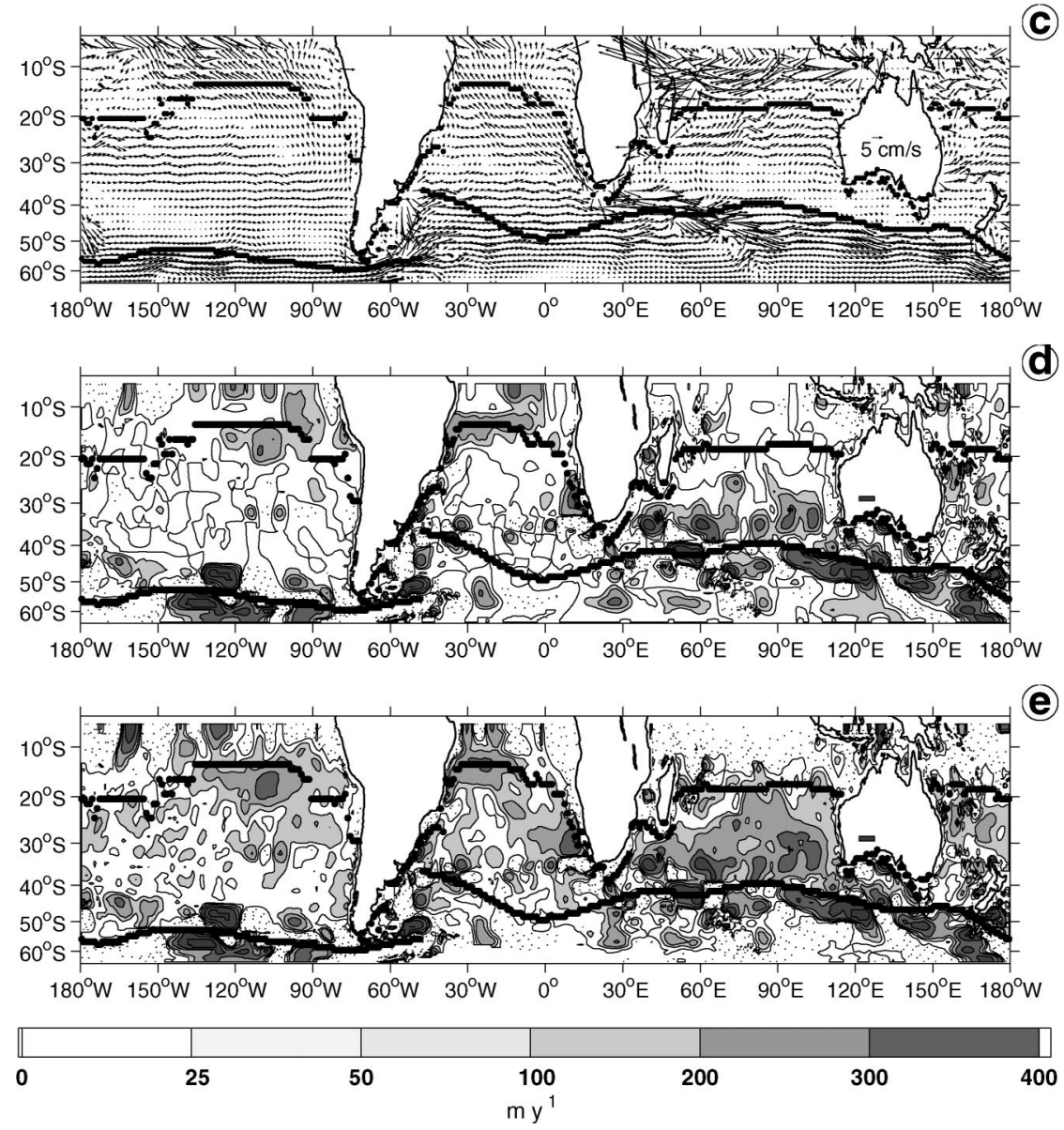

FIG. 2. (a) Ekman pumping velocity $\left(-w_{\mathrm{Fkm}}\right.$ ) calculated from SOC wind stress data (Josey et al. 1999). (b) Vertical velocity at the base of the deepest mixed layer $\left(-w_{h}\right)$. (c) Mean geostrophic velocity field in mixed layer calculated from the WOA data using $2000 \mathrm{~m}$ as a level of no motion. Only every second data point is shown. (d) Northward lateral component of subduction rate ( $-v$ $\partial h / \partial y)$. (e) Annual mean subduction rate (vertical flux and northward lateral input). Note the nonlinear grayscale. Thick black lines give boundaries of the subduction regions used for the integral calculations. 
TABLE 1. Subduction of water from mixed layer into the permanent thermocline of the Southern Hemisphere oceans in Sverdrups, calculated with the kinematic method. We define a standard case using SOC climatology wind, $0.125 \mathrm{~kg} \mathrm{~m}^{-3}$ mixed layer depth criteria, and a 2000-m reference level for the geostrophic velocity field. The second column gives for the standard case the resulting transport for east, north, west, and south components of the lateral induction ( $\mathbf{u}^{h}$. $\boldsymbol{\nabla} h)$ : the Ekman pumping transport component $\left(-w_{\mathrm{Ekm}}\right)$; and the effective vertical transport component $\left(-w_{h}\right)$. The maximum deviation from these values using different criteria is shown in the three right columns. We changed successively mixed layer criteria $(0.075 \mathrm{~kg}$ $\mathrm{m}^{-3} ; 0.2 \mathrm{~kg} \mathrm{~m}^{-3}$ ), wind fields (Hellerman and Rosenstein 1983; original and $20 \%$ reduced), and reference levels (1750 and $2500 \mathrm{~m})$. The values used for further discussion of the transport are emphasized in boldface.

\begin{tabular}{|c|c|c|c|c|c|c|}
\hline & & & & \multicolumn{3}{|c|}{$\begin{array}{c}\text { Maximum deviation from } \\
\text { standard }(\%)\end{array}$} \\
\hline & \multicolumn{3}{|c|}{ Standard } & \multirow{2}{*}{$\begin{array}{l}\text { Mixed } \\
\text { layer }\end{array}$} & \multirow{2}{*}{$\begin{array}{l}\text { Wind } \\
\text { field }\end{array}$} & \multirow{2}{*}{$\begin{array}{c}\text { Refer- } \\
\text { ence } \\
\text { level }\end{array}$} \\
\hline & Atlantic & Indian & Pacific & & & \\
\hline$-u \partial h / \partial x$ & 17.3 & 10.7 & 30.5 & 25 & - & 9 \\
\hline$+u \partial h / \partial x$ & -9.4 & -2.6 & -10.1 & 29 & - & 11 \\
\hline$-v \partial h / \partial y$ & 10.1 & 17.8 & 23.3 & 19 & - & 9 \\
\hline$+v \partial h / \partial y$ & -17.3 & -17.9 & -27.8 & 15 & - & 5 \\
\hline$-w_{\mathrm{Ek} m}$ & 16.4 & 21.4 & 28.7 & - & 19 & - \\
\hline$-w_{h}$ & 11.2 & 17.5 & 20.8 & 1 & 26 & - \\
\hline
\end{tabular}

the results on variations in the reference level (Table 1).

In the subduction regions the dominant features in the mean flow field in the mixed layer (Fig. 2c) are the South Atlantic, south Indian and South Pacific Ocean Currents that are related to the Subtropical Front (Stramma and Peterson 1990; Stramma 1992; Stramma et al. 1995). In the South Atlantic and in the south Indian Ocean they merge with the ACC into a broad band of eastward flow. The largest velocities exist in Drake Passage and south of Africa in the Agulhas Retroflection. The central outcrop regions are dominated by the weak anticyclonic recirculation of the subtropical gyres. The South Atlantic shows a band of northwestward currents, emanating from the Agulhas Current off South Africa. In the south Indian Ocean the flow field in the southern part of the ventilated zone is weak, but picks up northward speeds in the northern half. The strong South Equatorial Current fed by the Pacific inflow through the Indonesian Archipelago lies north of the subduction region. In the South Pacific the Subtropical and Subantarctic Fronts are well separated and the South Pacific Ocean Current is a distinct zonal current band that approaches the American coast at around $35^{\circ} \mathrm{S}$.

The contribution of the lateral flux through the inclined base of the winter mixed layer was calculated separately for the zonal and meridional current components. Positive (mean flux into the thermocline, that is subduction) and negative contributions (flux out of the thermocline) were summed separately (Table 1). Karstensen and Quadfasel (2002) argued that only the northward meridional flux irretrievably transfers water into the thermocline of the south Indian Ocean, and we will here follow their approach. We will address this issue again when comparing kinematic and water age subduction rates. The distribution of the estimated lateral subduction is shown in Fig. 2d. Its spatial pattern is noisy. This is not surprising as the lateral subduction term is a combination of two noisy components- the horizontal gradient of the topography of the mixed layer base (see Fig. 1) and the horizontal gradient in density used to calculate the geostrophic velocities (Fig. 2c). Since our later discussion of subduction rates is based on regionally integrated quantities we refrain from showing heavily smoothed maps here. We believe that the reader is capable of picking out the main features.

Local rates are largest in the southern part of the outcrop regions where both horizontal currents and the slopes of the mixed layer base are largest. High rates are also found between $15^{\circ}$ and $20^{\circ} \mathrm{S}$ in the Atlantic and eastern South Pacific Oceans, associated with the bowl shape of the subtropical gyres and a northward component in the South Equatorial Currents (SEC) in both oceans. In the Indian Ocean the outcrop region does not cover the SEC, so there is no second northern maximum in the subduction. However, the overall lateral subduction rates here are higher than in the two other oceans. The small meridional extent of the Indian Ocean subtropical gyre results in a relatively steep topography of the mixed layer base, giving rise to the strong lateral fluxes.

\section{4) Total subduction}

The sum of the vertical and horizontal components of the subduction is shown in Fig. 2e. The high wavenumber variability of the lateral input also obscures the total subduction, but at lower latitudes the effect of vertical pumping clearly dominates. Exceptions are the aforementioned high lateral inputs associated with the SECs in the Atlantic and the northeastern South Pacific at about $15^{\circ} \mathrm{S}$. Frontal regions in the Brazil-Malvinas confluence zone and northeast of Drake Passage in the Atlantic, and the Subtropical and Subantarctic Fronts in the Indian and the Pacific are associated with large lateral input. The lateral input between $140^{\circ}$ and $120^{\circ} \mathrm{W}$ may be associated with the merging of the Subantarctic and Polar Fronts here (Orsi et al. 1995).

An integrated view on the distribution of the subduction in the three oceans is given in Fig. 3, showing individual subduction rates at grid points versus the winter outcrop density, together with their averages over $0.2 \mathrm{~kg} \mathrm{~m}^{-3}$ increments. The scatter of the individual data points reflects the spatial variability of the rates rather than errors in the determination of the rates.

In the South Atlantic (Fig. 3, upper panel) lateral subduction dominates the lowest-density water (about $24.9 \mathrm{~kg} \mathrm{~m}^{-3}$ ), where "Subtropical Underwater" is formed (Tomczak and Godfrey 1994; Stramma and England 1999; Mémery et al. 1996), water at 26.1-26.7 kg $\mathrm{m}^{-3}$ where mode waters are formed in the Brazil-Mal- 

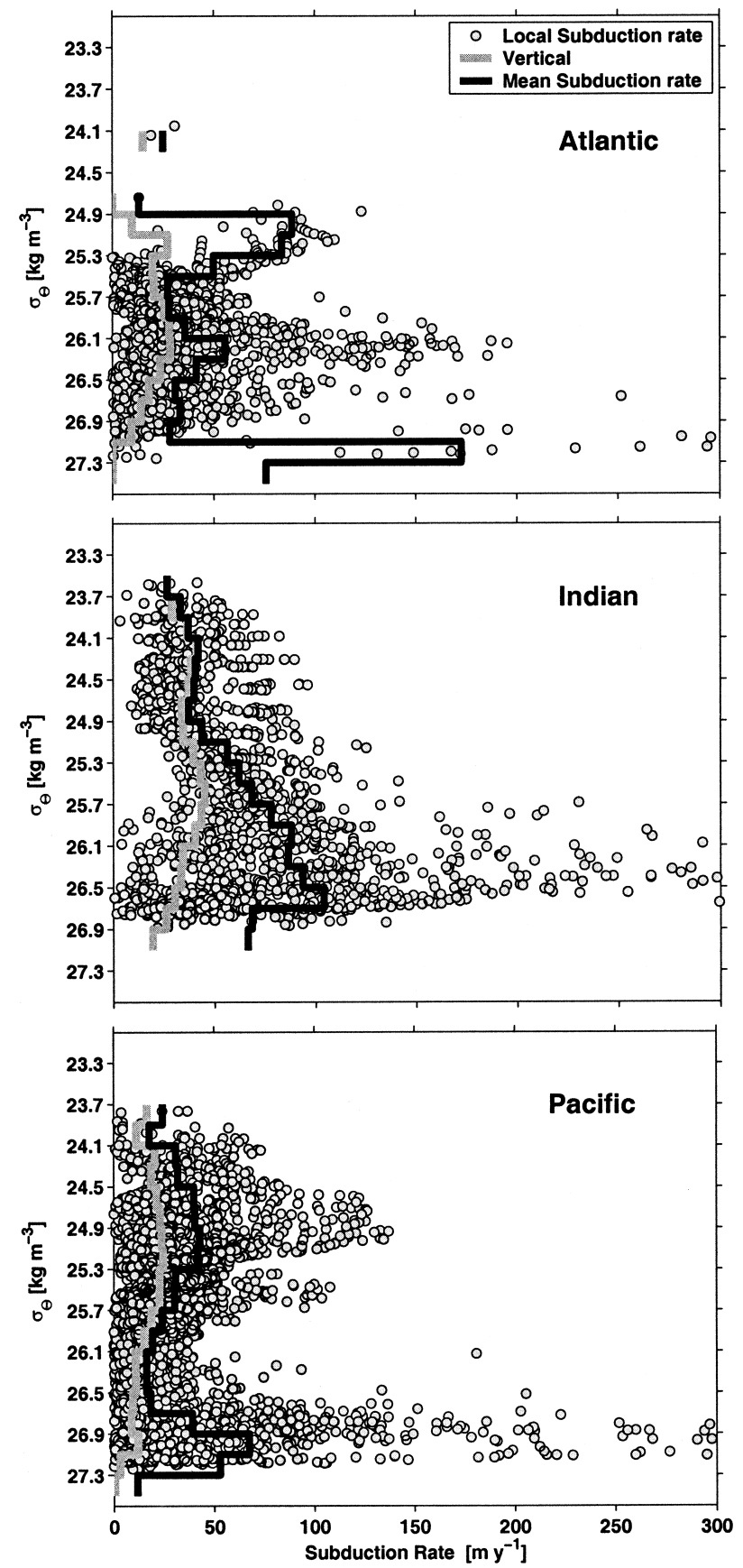

FIG. 3. Local subduction rates determined from the kinematic approach as sum of the vertical and northward lateral component (dots) vs the outcrop density anomaly. The average vertical velocity over the outcrop regions (light gray line), and averaged total subduction rate (black line) over $0.1 \mathrm{~kg} \mathrm{~m}^{-3}$ density increments.

vinas confluence zone (McCartney 1977, 1982; Gordon 1981; Mémery et al. 1996), and densities larger than $27.1 \mathrm{~kg} \mathrm{~m}^{-3}$ where intermediate water is subducted. For the south Indian Ocean the lateral input is large for densities $>25.4 \mathrm{~kg} \mathrm{~m}^{-3}$, which is in agreement with a wide range of mode waters (McCartney 1977, 1982;
Fine 1993; Karstensen and Quadfasel 2002) and associated with the band of very deep winter mixed layers. In the South Pacific a good part of the outcrop regions are ventilated through vertical pumping. Densities between 24.1 and $25.1 \mathrm{~kg} \mathrm{~m}^{-3}$ (Subtropical Underwater) and densities $>26.7 \mathrm{~kg} \mathrm{~m}^{-3}$ show enhanced lateral input down to the mode/intermediate water density near 27.3 $\mathrm{kg} \mathrm{m}^{-3}$ (Tsuchiya and Talley 1996). One might note here that Huang and Qiu (1998) did not identify in there analysis the subduction of the densest water and they suspected the smoothing in the climatology to be responsible for this.

\section{b. Water age approach}

The second method to estimate subduction rates is the water age approach, proposed by Jenkins (1987). It uses vertical water age gradients in the thermocline calculated for example from transient tracer data such as CFCs or the helium/tritium pair. Geostrophy and conservation of potential vorticity are assumed. The water age in the mixed layer is taken as zero. The age $(\tau)$ of a parcel in the interior, with a vertical distance $\partial z$ from the overlying mixed layer, is controlled through the instantaneous subduction rate. If vertical velocity shear and mixing are weak, the vertical age gradient between two neighboring isopycnals $(\partial \tau / \partial z)$ reflects the age that the water at the lower isopycnal had when the upper was about to leave the mixed layer, but still had an age of zero. Relating outcrop $\left(f_{0}\right)$ and observation $(f)$ planetary vorticity accounts for layer shrinking through conservation of potential vorticity [see Williams et al. (1995) for the formal derivation]. The water age approach subduction rate can be written as (Jenkins 1987; Williams et al. 1995)

$$
S_{\tau}=f_{0} / f(\partial \tau / \partial z)^{-1} .
$$

An important difference between the kinematic approach and the water age approach is their consideration of subduction forced by eddies. Using the kinematic approach on a climatological field, the contribution of eddies cannot be considered unless they are stationary. In contrast, the water age approach takes all contributing factors into account that transfer the water into the interior as it analyses the subduction out of an individual parcel. A comparison of the results from both approaches may allow an estimate of the transient eddy contribution to the subduction (Karstensen and Quadfasel 2002).

We calculated the vertical age gradient using CFC11 and CFC-12 data from WOCE cruises (see map Fig. 4). An apparent concentration age was obtained by transferring CFC data to their atmospheric equivalent using the solubility function (Warner and Weiss 1985) and comparing it with the atmospheric time history (Walker et al. 2000), assuming 100\% saturation in the formation region. As the atmospheric CFC content increases over time up to the end of the 1980s, lateral 


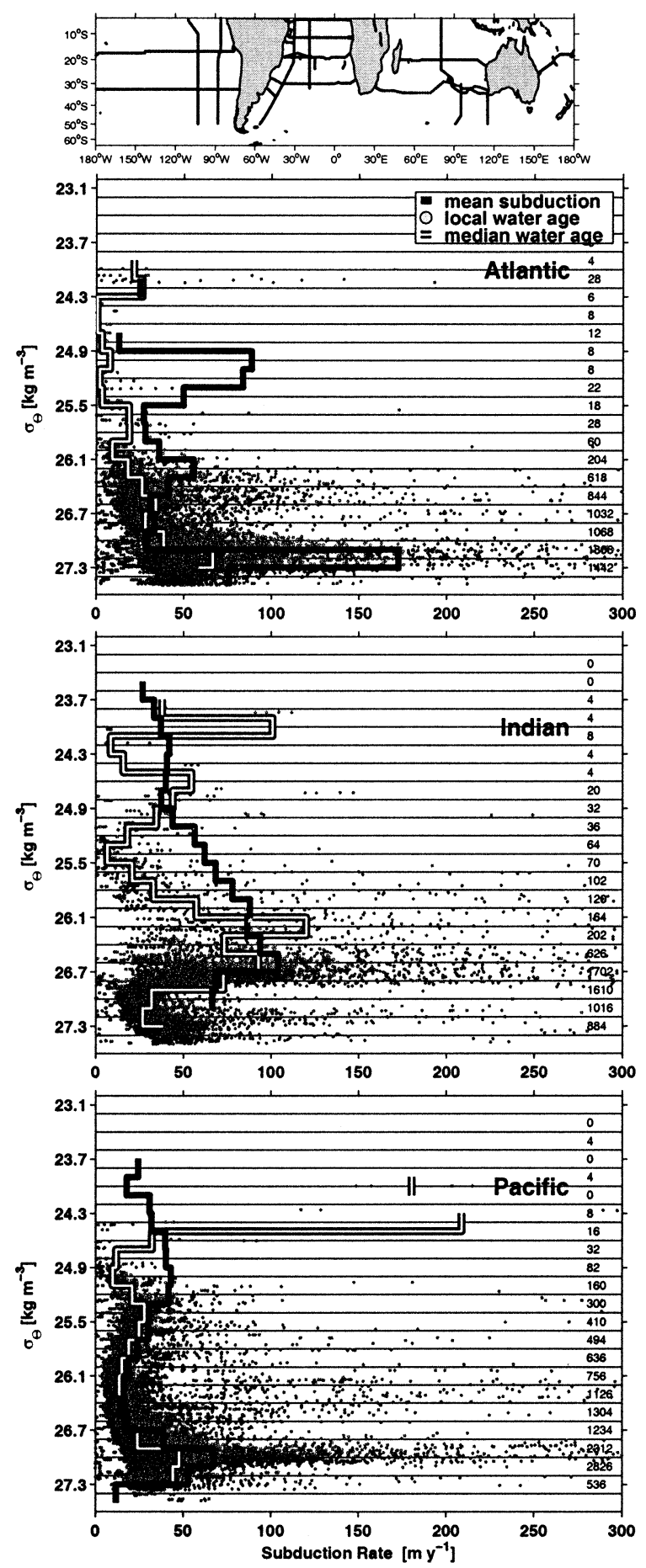

FIG. 4. Subduction rates estimated from the water age approach in relation to winter outcrop density anomaly. White line is the median of the water age rate, and black line is the averaged annual-mean subduction rate as calculated from the kinematic approach (see Fig. 3). Since the data distribution is sparse, in particular in the lower density classes, we found the median to be more appropriate than a Gaussian average to represent mean conditions. On the right-hand side the number of observations in each density bin is given. See map on top for location of samples (WOCE data: Atlantic A7, A8, A9, A10, A15, A17; Indian I3, I8, I9, I5; Pacific P6, P18, P19, P21). mixing causes the CFC apparent ages to be biased towards younger ages. As we use here the vertical age gradient rather than the absolute age, the effect of mixing is reduced because ages on neighboring isopycnals are biased in the same direction. However, to account for the mixing effect on the age, which is about $10 \%$ (relative error), we used the error map of Karstensen and Tomczak (1998). Another potential source of error is the vertical increment of data sampling (typically 50 $\mathrm{m}$ in the upper $500 \mathrm{~m}$ and $100 \mathrm{~m}$ down to $1000 \mathrm{~m}$ ) as subsurface maximum/minimum values in ages are not fully resolved. This influences mode water samples in particular as they are characterized through a subsurface age minimum and results in overestimating the rate. However, as mode waters usually occur in thick layers, the age minimum is rather broad and should be well sampled. Another source of error is the saturation assumption: if the waters were not saturated, the rate would be underestimated.

The outcrop latitude for each interior data point needed to calculate $f_{0}$ was determined with a polynomial fit on the WOA outcrop density. The standard deviation of each ocean individual fit was used to evaluate one source of error in the calculation (S. Atlantic $\pm 3.7^{\circ}, \mathrm{S}$. Indian $\pm 2.6^{\circ}$, and $\mathrm{S}$. Pacific $\pm 2.2^{\circ}$ ). We derived two subduction rates for each observation, one for the maximum outcrop and one for the minimum outcrop density.

The subduction rates based on tracer age are compared with those from the kinematic approach using the outcrop density as reference (Fig. 4). Of course, the WOCE sections cover only part of the subtropical gyres and the distribution of observational data is nonuniform compared to the gridded climatologies. As the waterage-based rates are "parcel dependent," they may not cover some subduction regions while others might be oversampled. In particular the low density waters are sparsely sampled. They occupy a relatively small volume in the gyre and the age tracer method needs water with even lower density as a reference to calculate the age gradient. The water age rates may thus not be representative for the whole outcrop region and the averages in density classes have to be seen in relation to the amount of data available (as indicated in Fig. 4). As in case of the kinematic rates the scatter cannot be solely interpreted as uncertainties, but also reflects the variability of the input into a specific density bin. For denser waters, data coverage is good and the results in general support our findings from the kinematic approach.

In the South Atlantic sampling starts to be sufficient (using about 100 data points as threshold) for densities larger than $25.9 \mathrm{~kg} \mathrm{~m}^{-3}$. Centered at about $26.5 \mathrm{~kg} \mathrm{~m}^{-3}$ the input of mode water from the Brazil-Malvinas confluence zone is evident. Largest input is seen for mode/ intermediate water with densities between 27.1 and 27.3 $\mathrm{kg} \mathrm{m} \mathrm{m}^{-3}$ with lower median age tracer than averaged kinematic approach rates. However, the average kinematic approach here is based on only a few grid points. In the Indian Ocean sampling starts to be sufficient at 
$25.3 \mathrm{~kg} \mathrm{~m}^{-3}$ where tracer age rates are again lower than those from the kinematic approach. Largest input occurs from about 26.3 to $26.9 \mathrm{~kg} \mathrm{~m}^{-3}$ (Karstensen and Quadfasel 2002). A second maximum in the input can be seen for densities around $27.3 \mathrm{~km} \mathrm{~m}^{-3}$ that may be associated with lateral input through the second, slightly shallower mixed layer trough at about $55^{\circ} \mathrm{S}$, which is not resolved in the kinematic approach. In the South Pacific the ventilated outcrop densities are well sampled for densities $>24.9 \mathrm{~kg} \mathrm{~m}^{-3}$ and the averaged subduction rates from both approaches agree well. For densities of about $26.9-27.3 \mathrm{~kg} \mathrm{~m}^{-3}$ high rates indicate lateral induction of mode/intermediate water. The scatter of local rates for the density range from 26.1 to $26.5 \mathrm{~kg} \mathrm{~m}^{-3}$ indicates lateral induction and hence mode water formation here too. Subtropical Underwater formation cannot be resolved due to the sparse data in the warmer and less dense waters.

The comparability of the subduction rates obtained by the two methods is of course limited, but some definite conclusions can be drawn. Over most of the density range the kinematic method leads to similar or even higher subduction rates than the water age approach. This supports our assumption that only the northward lateral component in the kinematic method contributes to the subduction into the thermocline is justified. Taking also the other components (south, east, west) in account would lead to an even larger discrepancy between the two methods. Secondly, transient eddies, which are only included in the tracer age estimate, cannot play a major role in overall the Southern Hemisphere thermocline water subduction process. Support of this idea comes from other observational studies: Garabato et al. (2001) found eddy-driven subduction rates in the order $20 \mathrm{~m} \mathrm{yr}^{-1}$ for the Southern Ocean fronts, which is an order of magnitude smaller than local lateral subduction rates.

\section{c. Volume fluxes}

Integrating the local subduction rates at the grid points from the kinematic approach (Fig. 3) over the outcrop areas and in density classes gives the volume transfer of waters into each of the Southern Hemisphere gyres (Fig. 5; Table 1). In the Atlantic the lateral transfer dominates the subduction at low densities (25.1-25.3 $\mathrm{kg} \mathrm{m}^{-3}$ ), driving water into the upper thermocline and creating the shallow Subtropical Underwater associated with a salinity maximum (Mémery et al. 1996). Lateral input increases for densities of $25.9-26.3 \mathrm{~kg} \mathrm{~m}^{-3}$ associated with the Subtropical Mode Water originating in the Brazil-Malvinas confluence zone (Gordon 1981; Provost et al. 1999; Mémery et al. 1996). For the densities centered at $27.1 \mathrm{~kg} \mathrm{~m}^{-3}$ the lateral input is the sole contributor that subducts intermediate water. Overall the South Atlantic is ventilated with a transport of about $21 \mathrm{~Sv}$ with equal lateral and vertical contribution. Sloyan and Rintoul (2001a) found a ventilation of 16
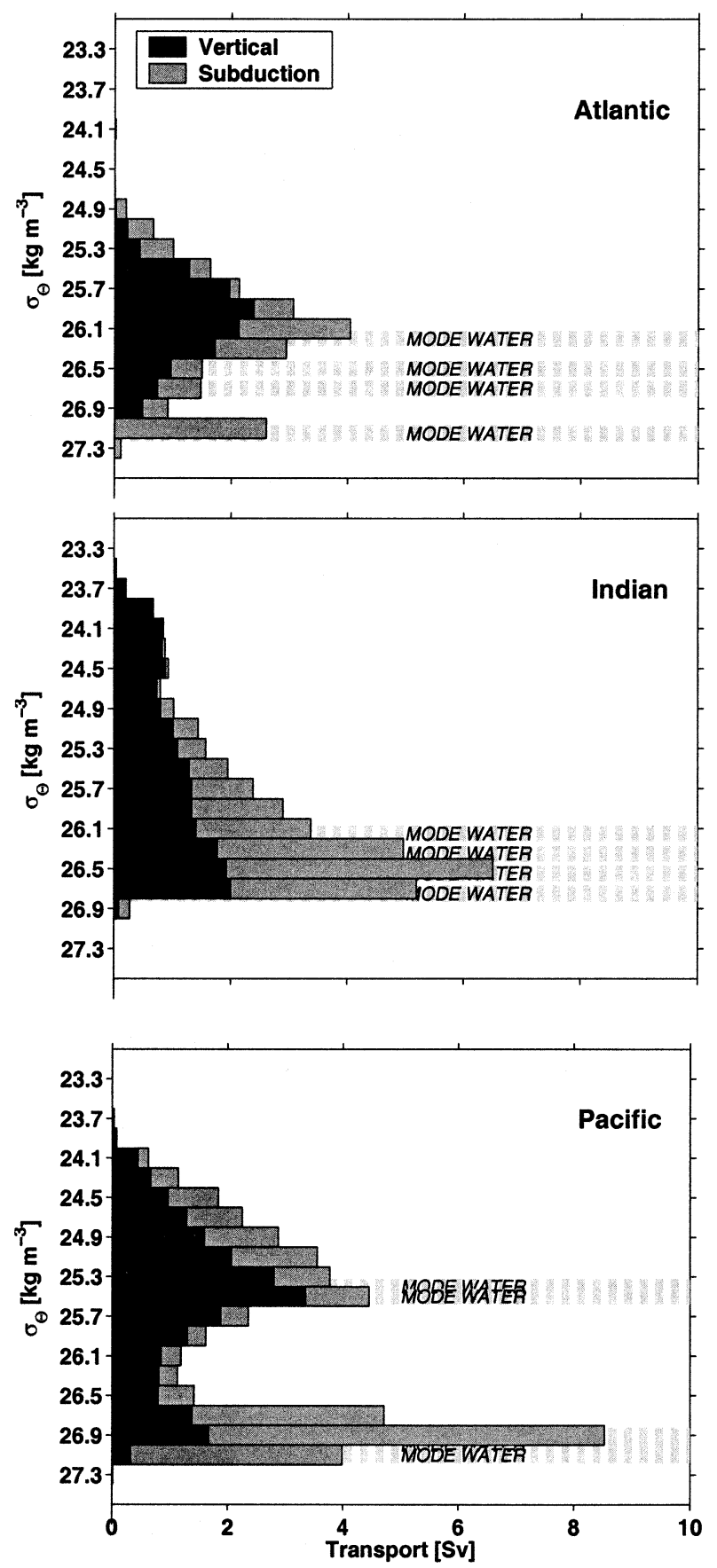

FIG. 5. Volume transfer derived from area of the winter outcrop density bins using the vertical velocity component (black) and total annual mean subduction rate (gray). Mode water density anomalies as found in the literature are indicated as broken lines (see text for references).

$\mathrm{Sv}$ south of $12^{\circ} \mathrm{S}$ for the layer between 26 and 27.4 $\mathrm{kg} \mathrm{m}^{-3}$, which corresponds well to our estimate of 14 $\mathrm{Sv}$ for the same density range.

The south Indian Ocean is discussed in detail in Karstensen and Quadfasel (2002). The transports (Fig. 5) presented here are slightly higher due to the use of the 


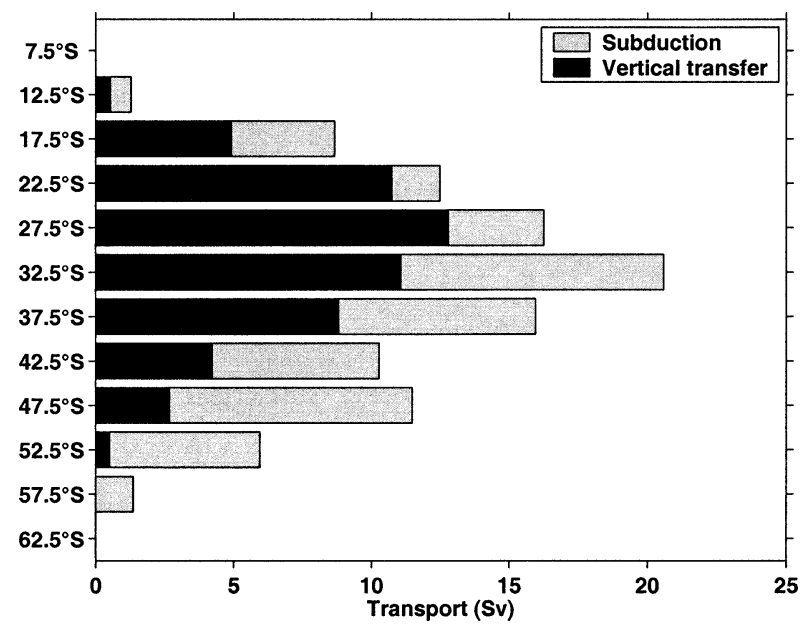

FIG. 6. Meridional integrated transport into the Southern Hemisphere permanent thermocline: vertical component (dark gray) and total annual mean subduction (light gray).

SOC wind data. Lateral fluxes (17 Sv) are similar to the vertical ones $(18 \mathrm{~Sv})$. Again the lateral rates dominate at mode water densities (McCartney 1977, 1982; Fine 1993; Karstensen and Tomczak 1998). In the South Pacific the subduction has a bimodal distribution in density space. Transports peak at $25.5 \mathrm{~kg} \mathrm{~m}^{-3}$ for the northeastern area of the outcrop with dominating vertical transfer. A second peak from 26.7 to $27.1 \mathrm{~kg} \mathrm{~m}^{-3}$ is mainly laterally driven and covers Subantarctic Mode and Intermediate Water densities (McCartney 1977, 1982; Tsuchiya and Talley 1996). The overall transport in the South Pacific is $44 \mathrm{~Sv}$ of which the vertical transport contributes a little less than half. For water $<25.1$ $\mathrm{kg} \mathrm{m}^{-3}$ lateral and vertical input is about equal and forms the shallow salinity maximum $(S>36.6 \mathrm{psu})$ of Subtropical Underwater (Tsuchiya and Talley 1996). Our vertical Pacific transports agree with the results of Huang and Qiu (1998) while our lateral transport estimates (excluding the dense mode/intermediate waters) are about 4 times higher.

Meridionally integrating the fluxes over zonally averaged bands of $5^{\circ}$ latitude, the vertical transfer of water between the mixed layer and thermocline is about 50 Sv (Fig. 6) and thus equal to the lateral induction. Lateral transfer for densities associated with Subantarctic Mode/Intermediate Waters $\left(26.5-27.2 \mathrm{~kg} \mathrm{~m}^{-3}\right)$ is of the order of $30 \mathrm{~Sv}$ and thus compatible with the transformation of Antarctic Surface Water to mode and intermediate water, which Sloyan and Rintoul (2001a) estimated to be $34 \mathrm{~Sv}$. Taking the transport into the Northern Hemisphere thermocline into account (Huang and Qiu 1994) the global thermocline ventilation is about $160 \mathrm{~Sv}$.

The uncertainties of the calculations with respect to the choices of the mixed layer criteria, the reference level for the geostrophic calculations, and wind stress climatologies are summarized in Table 1. Maximum changes in the fluxes are of order $20 \%$ for the different mixed layer criteria and choice of wind fields, and somewhat less for the two different reference levels. These uncertainties are large, but do not change our main conclusions. In addition, we simulated the effect of mesoscale eddies on the lateral transfer with a simple approach: on the lateral induction field we superimposed random noise with an amplitude of $20 \mathrm{~m} \mathrm{yr}^{-1}$ (Garabato et al. 2001) and recalculated the transports. The largest changes are found in the Indian Ocean, which has the widest range of mode waters, with an increase of about $25 \%$ for the lateral induction and of about $10 \%$ for the total flux. Again, this does not change our main conclusions.

\section{Water mass transformation and variability}

The transfer of water into the thermocline must be supported by the formation of surface water through air-sea fluxes. Air-sea fluxes change temperature and salinity characteristics of the surface water and transform water from one density to another. The divergence of the transformation is the formation of water that should be compensated through interior fluxes and may allow a further estimate of the subduction rates (Speer 1997; Marshall et al. 1999). As Marshall et al. pointed out, both quantities, the flux divergence and the subduction, are different in a sense that the air-sea flux is an integral flux of creation while the subduction is a local transfer between mixed layer and thermocline. Diffusive processes will lead to deviations between both, thus limiting the possibility of comparison. We will try to account for this by comparing the overall formation of thermocline waters in the Southern Hemisphere sectors of the oceans, as calculated above, with the formation calculated from air-sea interaction.

Surface water mass transformation combines density fluxes derived from heat and freshwater fluxes at the air-sea interface with a mass budget on individual outcropping density layers (Walin 1982; Tziperman 1986; Speer and Tziperman 1992). The density flux at the sea surface is (e.g., Gill 1982; Schmitt et al. 1989)

$$
F_{\rho}=\frac{-\alpha \mathcal{H}}{c_{W}}+\beta \rho(T, S) \frac{(E-P) S}{1-S} .
$$

Here $c_{W}$ is the heat capacity of water, $\mathcal{H}$ is the surface net heat flux, $E-P$ is the net freshwater flux, $\alpha$ is the coefficient of thermal expansion of seawater, $\beta$ is the haline contraction coefficient, $S$ is the salinity, and $\rho(T, S)$ is the surface density. In general all variables are functions of location and time. Using monthly data the mass budget in discrete density bins of $\left[\Pi\left(\rho-\rho^{\prime}\right)\right]$, over a $1^{\circ} \times 1^{\circ}$ area element $\Delta A_{i, j}$ can be diagnosed from

$$
F_{m}=\frac{1}{\Delta \rho} \sum_{n=1}^{12} \Delta t \sum_{i, j} \Delta A_{i, j} F_{\rho i, j}^{n} \prod\left(\rho-\rho^{\prime}\right) .
$$

The convergence (divergence) of the so-calculated 

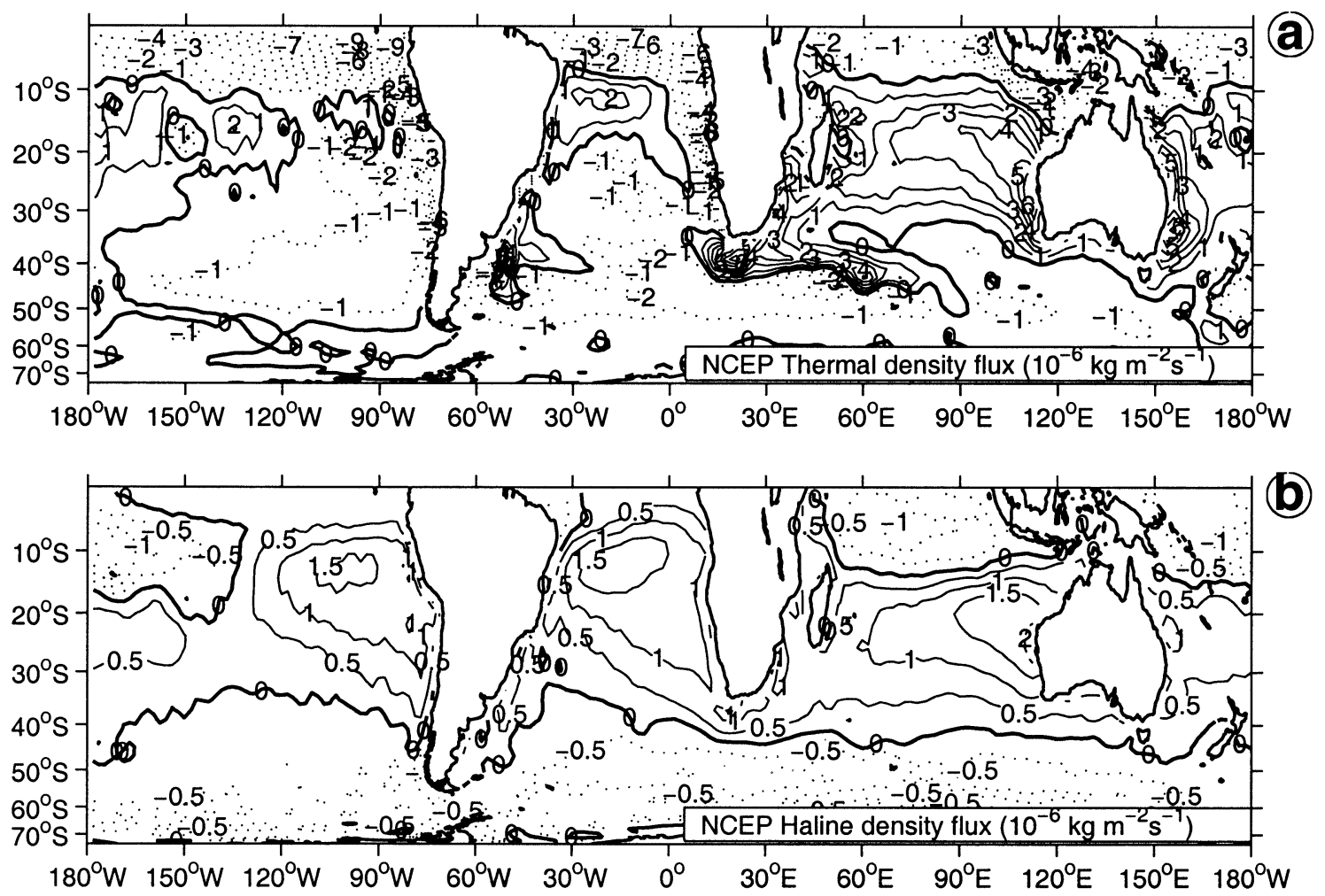

FIG. 7. Averaged (a) thermal and (b) haline density flux component from NCEP-NCAR reanalysis data, Reynolds sea surface temperature, and WOA salinity. Negative (out of the ocean) fluxes are stippled. Note that contouring is different for thermal $\left(1 \times 10^{-6} \mathrm{~kg} \mathrm{~m}^{-2} \mathrm{~s}^{-1}\right)$ and haline $\left(0.5 \times 10^{-6} \mathrm{~kg} \mathrm{~m}^{-2} \mathrm{~s}^{-1}\right)$ fluxes.

transformation corresponds to the formation (destruction) of water masses.

A crucial point for the calculation of water mass formation rates is the quality of the surface flux data and their compatibility with the oceanic surface density field. Older climatologies, such as the Comprehensive Ocean-Atmosphere Data Set (COADS), are usually based on a number of individual observations, such as from ships or drifting buoys, distributed irregularly in space and time. Gridding of such data makes sense when enough samples are available for the averaging, but becomes problematic where only few observations have been made, such as south of $45^{\circ} \mathrm{S}$. Consequently this region has often been excluded from analysis of water mass transformation in the past. Gridded datasets often do not close the global heat and freshwater cycle and as a zero order approximation a global bias is assumed (da Silva et al. 1994a,b).

Since the beginning of the 1980s, however, air-sea flux estimates improved significantly with the introduction of satellite-based remote sensing technologies. Now atmospheric datasets are produced routinely by assimilating all available observations into atmospheric general circulation models. The National Centers for Environmental Prediction (NCEP)-National Center for Atmospheric Research (NCAR) reanalysis data (Kistler et al. 2001) provides a dynamically consistent global da- taset with closed heat and freshwater budgets. In the analysis we use heat and freshwater fluxes derived from the NCEP-NCAR reanalysis. Particular attention was given to the time span 1982-99 when sea surface temperatures (based on Reynolds and Smith 1995) are available south of $45^{\circ} \mathrm{S}$ to account for the ocean's response on changes in the heat flux field. As no high-resolution salinity dataset is available, we simply use the WOA monthly salinity climatology to calculate the surface density field. Water mass transformations were estimated over relatively large density bins of $0.2 \mathrm{~kg} \mathrm{~m}^{-3}$. The annual mean water mass transformation is calculated from monthly data from January to December of each year.

\section{a. Climatological water mass transformation}

The spatial distributions of the mean NCEP-NCAR reanalysis based density flux components are shown in Fig. 7. The patterns compare well with published values based on climatologies (da Silva et al. 1994a,b; Speer 1997; Zhang and Talley 1998) but in the subtropics the fluxes are much higher. This discrepancy may arise from the mix of observational data of different atmospheric variability states in the climatology as well as from different flux parametrizations used in the climatology and the reanalysis (e.g., Moyer and Weller 1997; Josey 
2001). Closing the heat and freshwater budget in the da Silva et al. climatology is certainly another source of error leading to a bias.

In the South Atlantic there are two regions where the ocean gains density in the annual mean: the BrazilMalvinas confluence zone at about $40^{\circ} \mathrm{S}$ and a Subtropical Region between $10^{\circ}$ and $20^{\circ} \mathrm{S}$, west of the Greenwich meridian. Both areas show enhanced subduction through lateral flux (Fig. 2d), which is associated with Subtropical Underwater and Subantarctic Mode Water formation (Mémery et al. 1996). Haline fluxes are strongest in the subtropics. For the Indian Ocean we refer to Zhang and Talley (1998) for a detailed discussion of the density fluxes. Large thermal fluxes occur along the Australian coast and extend far into the gyre. South of Africa large thermal fluxes occur within the Agulhas Retroflection extending eastward along the southern rim of the subtropical gyre due to the advection of the warm recirculating surface water (England et al. 1993). The Pacific shows a bimodal distribution of fluxes: Large thermal-driven density fluxes can be found west of about $130^{\circ} \mathrm{W}$ along the Australian coast and are associated with the southward flowing East Australian Current. In contrast, the broad area in the east (east of $130^{\circ} \mathrm{W}$ ) is dominated by haline fluxes and only along the Peruvian and Chilean coast intense negative thermal fluxes (ocean heat gain) occur due to upwelling of deeper waters. Maximum haline fluxes are between $10^{\circ}$ and $20^{\circ} \mathrm{S}$ in the eastern South Pacific and Atlantic and about $10^{\circ}$ farther in the south Indian Ocean. In the Atlantic and Pacific these regions are associated with the lateral induction of Subtropical Underwater into the upper thermocline (see Fig. 2d).

Comparing the da Silva et al. water mass transformation rates with those derived from the NCEP-NCAR reanalysis shows similar overall patterns, but also large differences in certain density anomaly ranges (Fig. 8). Ship- and buoy-based observational data are sparse in the Southern Ocean and the da Silva et al. climatology excludes most of the dense waters, limiting the comparison to the lower density range. The annual mean values of the transformation rates from NCEP-NCAR reanalysis show a large scatter, and thus the differences between climatology and mean reanalysis are probably not surprising. Largest differences occur in the Indian Ocean at densities $<24 \mathrm{~kg} \mathrm{~m}^{-3}$ and in the Pacific at densities $<23 \mathrm{~kg} \mathrm{~m}^{-3}$, but in general the da Silva et al. estimates are within the scatter of annual NCEP-NCAR reanalysis values. Looking into the thermal and haline components we find the thermal component to be responsible for these differences, but we do not know why this occurs. In the following we will only discuss the NCEP-NCAR reanalysis derived transformation rates.

There are large similarities among the three oceans: A maximum in transformation occurs at around $25 \mathrm{~kg}$ $\mathrm{m}^{-3}$ (left bound of gray area in Fig. 8). The formation is the derivative of the transformation and this maximum separates formation of denser water from its destruction,
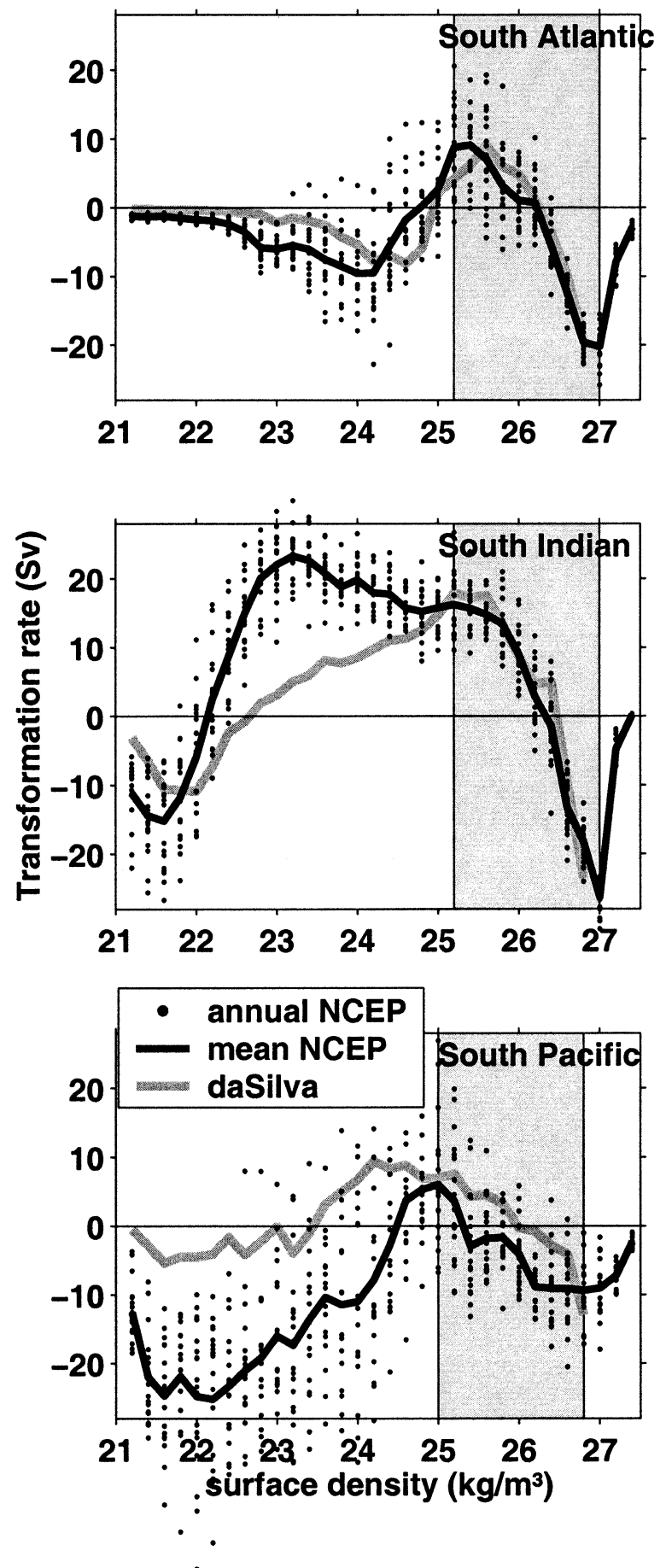

FIG. 8. Comparison of water mass transformation rates for individual Southern Hemisphere oceans calculated using daSilva et al. climatology and average (line) and annual mean (dots) NCEP-NCAR reanalysis data. WOA surface salinity and Reynolds surface temperatures are used to calculate the surface density. Integration is done in bins of $0.2 \mathrm{~kg} \mathrm{~m}^{-3}$. The respective density anomaly range to calculate the formation of thermocline waters is indicated by gray shaded areas. 
TABLE 2. Southern Hemisphere water mass formation (Sv) calculated using the kinematic method, the water age approach, and from the NCEP-NCAR reanalysis-based air-sea fluxes. The numbers in italics are transport as obtained by normalizing the overall Southern Hemisphere transport to that obtained from the kinematic approach.

\begin{tabular}{|c|c|c|c|c|c|c|}
\hline & Atlantic & & Indian & & Pacific & Sum \\
\hline Kinematic & 21 & & 35 & & 44 & 101 \\
\hline Water age & $14(18)$ & & $30(39)$ & & $33(43)$ & 77 (101) \\
\hline Air-sea interaction & $29(34)$ & & $43(50)$ & & $15(17)$ & 87 (101) \\
\hline Interbasin exchange & & (13) & & $(28)$ & & \\
\hline
\end{tabular}

or the formation of less dense waters. It may thus be interpreted as the boundary between the permanent thermocline and the seasonal or tropical thermocline outcrop (Speer and Tziperman 1992). At higher densities the minimum in the transformation around $27 \mathrm{~kg} \mathrm{~m}^{-3}$ indicates the upper limit of the density anomaly interval where water mass formation through buoyancy gain occurs. In the South Atlantic and south Indian Oceans it is a rather sharp peak, while in the South Pacific it is much broader. The transformation rates can be translated into water mass formation rates by taking the difference between minima and maxima (Fig. 8). In the South Atlantic $\left(70^{\circ} \mathrm{W}-20^{\circ} \mathrm{E}\right)$ we find about twice as large formation from dense water into less dense water (gray area in Fig. 8) than vice versa, with an overall of 29 $\mathrm{Sv}$. For the south Indian Ocean $\left(20^{\circ}-120^{\circ} \mathrm{E}\right)$ we find a formation of about $43 \mathrm{~Sv}$ with again higher transformation from dense into less dense water. For the South Pacific only about $15 \mathrm{~Sv}$ are formed. This is surprising since the Pacific is the widest of the three oceans.

The overall formation in the Southern Hemisphere is thus on the order of $90 \mathrm{~Sv}$. This number agrees with the overall subduction rate of $101 \mathrm{~Sv}$ estimated from the kinematic approach and $77 \mathrm{~Sv}$ using the averaged water age approach (Table 2). However, the distribution of the input is different. Subduction increases from west to east, being $21 \mathrm{~Sv}$ in the South Atlantic, $35 \mathrm{~Sv}$ in the south Indian, and $44 \mathrm{~Sv}$ in the South Pacific Ocean. Hence, some of the water formed in the South Atlantic must flow into the south Indian Ocean and even more water from the Indian Ocean must be exported into the South Pacific where it finally subducts. Sloyan and Rintoul (2001a), from an inverse model study, also detected such an interocean exchange of newly formed water masses via the circumpolar water ring. They found some $18 \mathrm{~Sv}$ to be exported from the Indian to the Pacific Ocean, in line with our findings (Table 2).

\section{b. Variability in water mass transformation}

As a next step we looked at the time series of monthly fluxes in the NCEP-NCAR reanalysis data to possibly detect trends or longer-term variability in the water mass formation. Variability in thermocline water formation, in particular the mode and intermediate waters formation, is affected by and may also be relevant for decadalscale climate variability. Warming and cooling signals at midlatitudes are communicated to the thermocline, are advected equatorward, and reappear due to upwelling in the Tropics at the surface ocean with decadal delay. These shallow thermohaline cells have been recognized as a communication path between Tropics and extratropics ( $\mathrm{Gu}$ and Philander 1997; Johnson and McPhaden 1999).

The time series of annual-mean water mass formation between 1982 and 1999 for the three oceans is given in Fig. 9. Also shown is the 5-yr running mean and the linear trend. We find a consistent increase in the overall water mass formation rates in all three oceans, which in the South Pacific is obscured by decadal variability. The trend originates from variability in the formation of less dense waters (not shown). For the whole Southern Hemisphere the curve is shown in Fig. 10. An extended time series from 1950 to 1999 was calculated considering only SST variability north of $45^{\circ} \mathrm{S}$ (gray curve). However, as the variability originates in the less dense waters there is good agreement with the results based on the shorter satellite-derived SST, which allows one to consider variability over the whole region (black line).

How does an increase in thermocline water formation compare with oceanic in situ observations? Levitus et al. (2000) showed a significant increase in the upper1000 -m heat content in all three oceans (using hydrographic data from 1948 to 1998). This agrees with our findings for the last 20 years, as an increase in the formation of thermocline waters will increase the depth of the thermocline and thus deepen the separation horizon with the "cold" deep waters. Most other observational based studies compare synoptic high-quality sections of particular years giving specific attention to mode and intermediate waters (e.g., Bindoff and Church 1992; Bindoff and McDougall 2000; Johnson and Orsi 1997; Wong et al. 1999; Shaffer et al. 2000). A warming and layer increase by about $70 \mathrm{~m}$ (or 25\%) of Subantarctic Mode Water as well as a freshening of the intermediate water was detected Bindoff and McDougall (2000) for the southern Indian Ocean. Not taking any change in the gyre circulation in response to a change in water mass volume into account, our transformation increase over this period (Fig. 9) agrees with such an increase in layer thickness. Banks et al. (2000) used a coupled climate model forced by anthropogenic changes and successfully simulated the thickness increase of the model's mode water, along with a freshening and cool- 

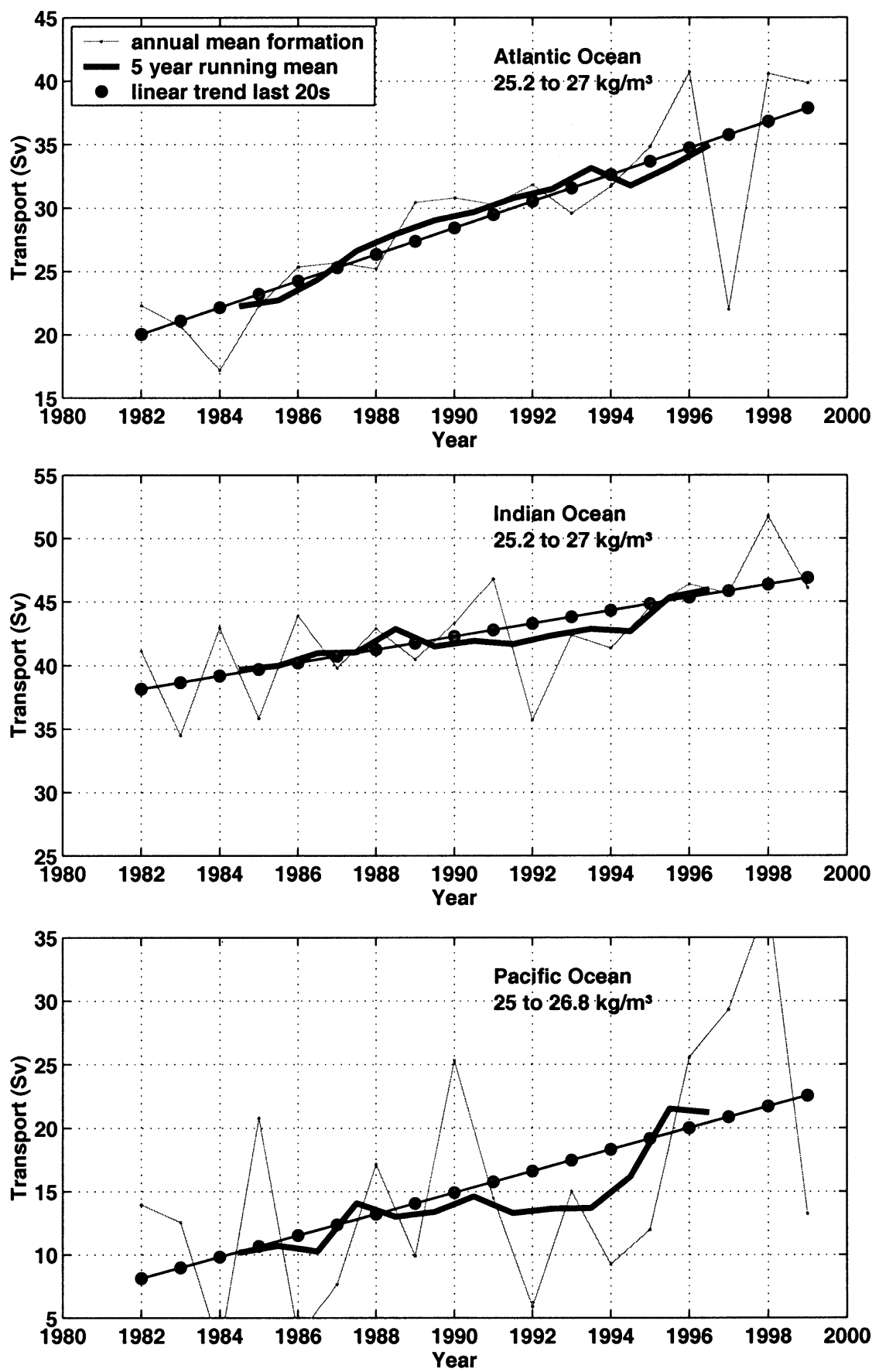

FIG. 9. Variability of Southern Hemisphere water mass formation (south of $5^{\circ} \mathrm{S}$ ) between 1982 and 1999 from NCEP-NCAR reanalysis data for the South Atlantic, the south Indian, and the South Pacific. Formation is calculated using the difference between maximum and minimum transformation densities given in upper-left corner.

ing on density surfaces. Although the connections between air-sea fluxes and subduction rates discussed above and between the flux variability and its response in the hydrographic field are encouraging, further comparison studies between locally measured heat fluxes and the reanalysis products are necessary.

\section{Summary and concluding remarks}

The permanent thermoclines in the subtropical gyres constitute about $15 \%-20 \%$ of the World Ocean volume. This volume is ventilated through subduction, which is the flux across the base of the mixed layer at mid- and 


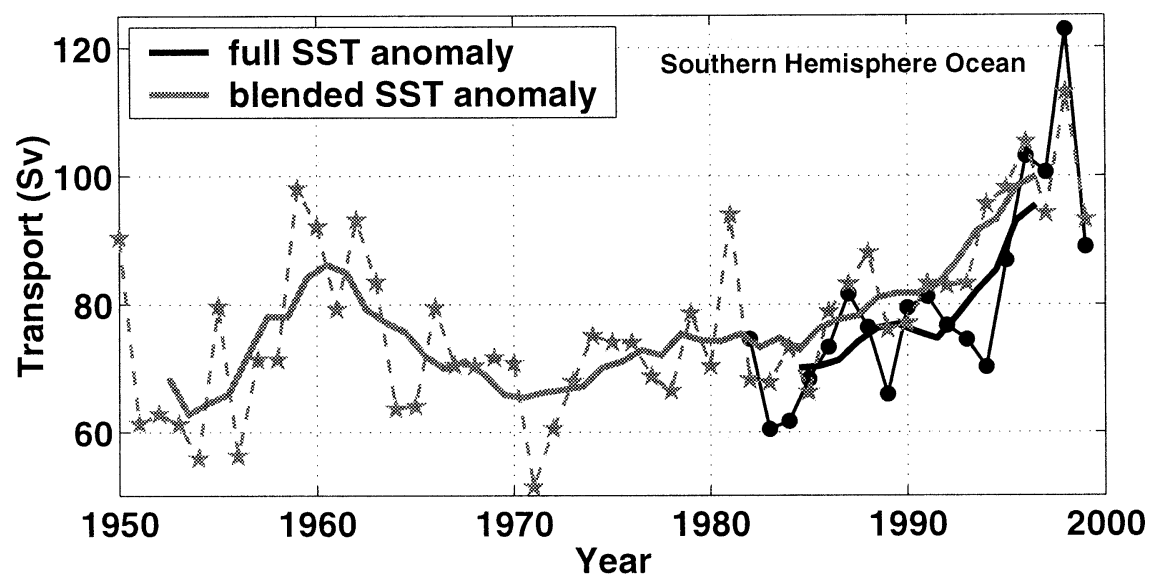

FIG. 10. Overall formation of Southern Hemisphere waters from surface density fluxes. The 1950-99 curve is based on calculations using Reynolds and Smith (1995) SST data but variable only north of $45^{\circ} \mathrm{S}$ (gray line); the 1982-99 curve is based, as in Fig. 9, on a global variable SST derived from satellite data (black line).

low latitudes (Luyten et al. 1983). In the Southern Hemisphere the associated circulation provides a route of communication between the deep and intermediate depth ocean (e.g., Schmitz 1996; Speer et al. 2000; Sloyan and Rintoul 2001b) and between the midlatitudes and the Tropics (Gu and Philander 1997; Johnson and McPhaden 1999). The waters in the thermocline store and release heat, freshwater, and greenhouse and other gases and therefore have the potential to act as a buffer for changes in the earth's climate system.

In this paper we investigated the outcrop of the Southern Hemisphere permanent thermocline and quantified the subduction of water ventilating the subtropical gyres. To do this, we employed three different and completely independent methods: 1) the kinematic approach in which the fluxes across the base of the mixed layer are determined directly (Woods 1985), 2) the water age approach where the ventilation is estimated indirectly from the distribution of tracer ages in the ocean's interior (Jenkins 1987), and 3) an indirect method using air-sea fluxes and determining the divergence of water mass transformation rates (Walin 1982). These methods were applied to historical hydrographic and atmospheric data, to synoptic tracer data from WOCE, and to air-sea flux data from the NCEP-NCAR reanalysis project.

Integrated over the whole of the Southern Hemisphere these three methods give subduction rates of 101, 77, and $87 \mathrm{~Sv}$, respectively (Table 2). The differences between the methods of up to $25 \%$ reflect some inherent deficiencies of the methods but mainly deficiencies of the datasets used. The Southern Hemisphere oceans, in particular the South Pacific, are poorly sampled and aliasing by synoptic features severely degrades the quality of the climatologies. Nevertheless, the overall agreement (within 25\%) of the ventilation derived from the three methods is encouraging. In order to make the estimates in the individual ocean basins compatible, we scale the numbers from the latter two methods (77 and
$87 \mathrm{~Sv}$ ) to that derived from the kinematic approach (101 $\mathrm{Sv})$. All estimates from the water age approach are thus multiplied by 1.31 and those derived from the air-sea fluxes by 1.16 (brackets in Table 2). This choice of the reference value of $101 \mathrm{~Sv}$ is of course arbitrary and one has to keep in mind that the overall uncertainties are at least in the order of $25 \%$. The main results of our study may be summarized as follows.

- The subduction of water into the South Atlantic, Indian and Pacific Ocean is 21, 35, and $44 \mathrm{~Sv}$, respectively. Vertical fluxes (reduced Ekman pumping) cause about half of the ventilation, lateral injection of mode waters supplies the other half (Tables 1 and 2; Fig. 11). Vertical fluxes ventilate mainly the upper part of the thermocline, lateral fluxes the lower part (Figs. 5 and 6).

- Seen globally, the strongest local subduction spirals southwestward from about $25^{\circ} \mathrm{S}, 100^{\circ} \mathrm{W}$ in the South Pacific through the South Atlantic and the south Indian Ocean to $55^{\circ} \mathrm{S}, 50^{\circ} \mathrm{W}$ near Drake Passage (Fig. 11). Most of this spiral is associated with the trough of deepest winter mixed layer depth (Fig. 1).

- Water mass formation rates based on the air-sea fluxes suggest a surplus of about $13 \mathrm{~Sv}$ for the South Atlantic and of $15 \mathrm{~Sv}$ for the Indian Ocean, and a deficit of $28 \mathrm{~Sv}$ for the South Pacific (Table 2; Fig. 11). If real, this requires an interbasin exchange of mixed layer water of 13 and $28 \mathrm{~Sv}$ from the South Atlantic to the south Indian, and from the south Indian to the South Pacific Ocean, respectively. Sloyan and Rintoul (2001a) found an exchange of $9 \mathrm{~Sv}$ from the South Atlantic to the Indian and of $18 \mathrm{~Sv}$ from the Indian to the South Pacific.

- The time series of surface density flux divergence suggests an increase of thermocline water formation by about $50 \%$, from about 70 to $110 \mathrm{~Sv}$ over the past 20 years. The associated warming and thickness increase 


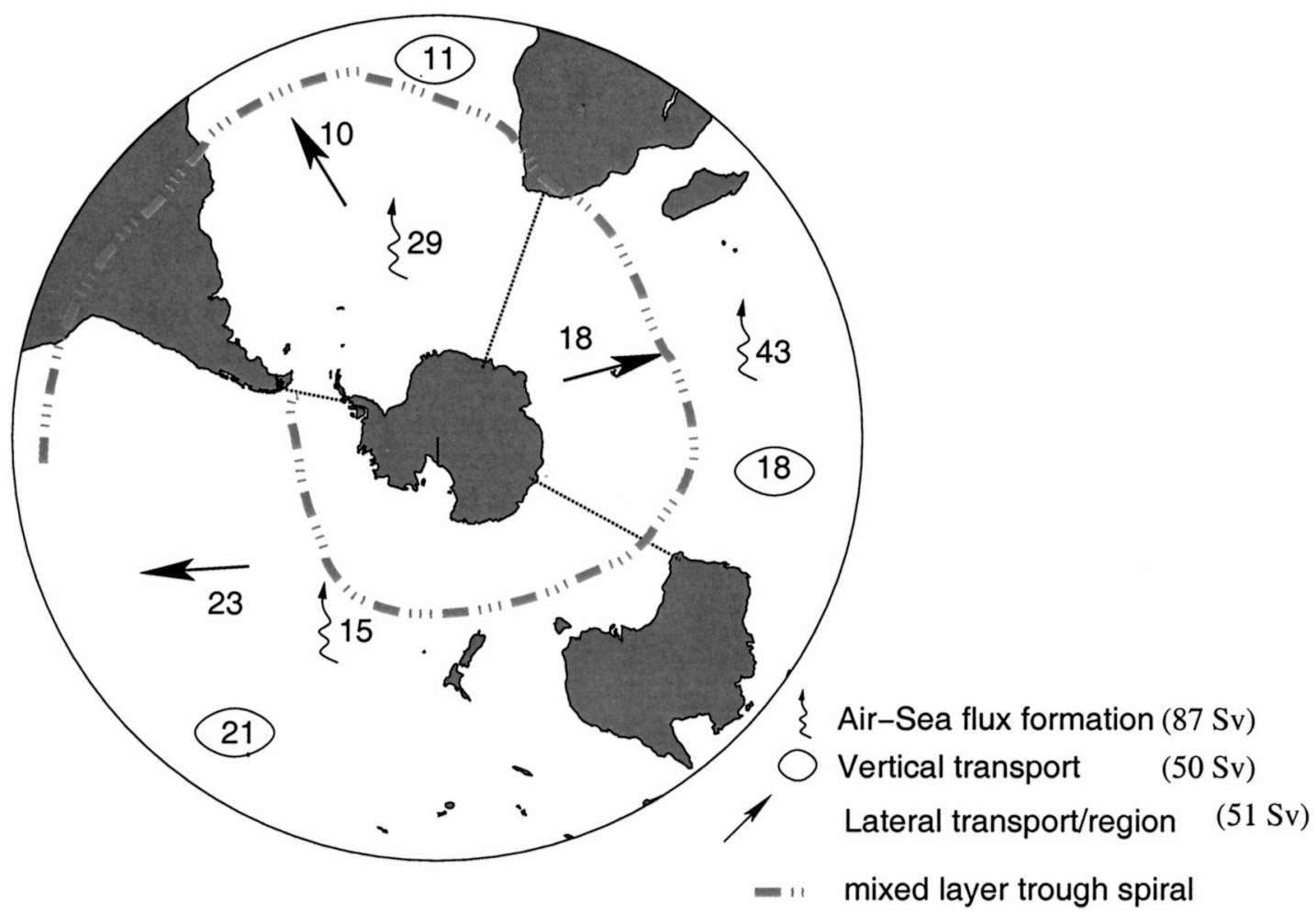

FIG. 11. Summary of transports into the permanent thermocline of the Southern Hemisphere ocean and production of the water through air-sea interaction.

of the thermocline have recently been confirmed (Levitus et al. 2000).

How can the quality of these estimates be improved? A largely open question concerning the methods is the role played by mesoscale eddies in the transfer of mixed layer waters into the thermocline. Our estimate of subduction from the water age approach, that considers this contribution, is lower than that of the kinematic approach, suggesting that eddies play a minor role. However, the estimates all have large uncertainties. In situ experiments resolving the contributing processes and supported by modeling work seem necessary to solve the issue.

A second issue concerns the improvement of air-sea estimates. The different climatologies used in this study yield different results and, although the trends seen in the reanalysis appear to be real, the absolute numbers derived from the water mass conversion may be substantially biased. Moyer and Weller (1997) and Josey (2001) compared observed fluxes in the subtropics with both climatological and reanalyzed data (NCEP-NCAR) and found substantial discrepancies in certain flux components. Therefore, direct air-sea flux measurements in the Southern Ocean seem desirable, but severe environmental conditions may prohibit such experimental work at present.
Acknowledgments. We are grateful to Lynne Talley and to two anonymous reviewers for their detailed and thorough comments and Kevin Speer for discussions on water mass transformation. The NCEP-NCAR reanalysis data are appreciated, as well as the Reynolds SST data provided by the NOAA-CIRES Climate Diagnostics Center, Boulder, Colorado, from their Web site http://www.cdc.noaa.gov/. Author JK enjoyed the hospitality of DCESS, Copenhagen, during a onemonth stay, during which this study was begun. Financial support is acknowledged from NOAA through Grant NA86GP0375 and from the German CLIVAR program, funded by BMBF.

\section{REFERENCES}

Banks, H. T., R. A. Wood, J. M. Gregory, T. C. Johns, and G. S. Jones, 2000: Are observed decadal changes in the intermediate water masses a signature of anthropogenic climate change? Geophys. Res. Lett., 27, 2961-2964.

Bindoff, N. L., and J. A. Church, 1992: Warming of the water column in the southwest Pacific Ocean. Nature, 357, 59-62.

—_, and T. J. McDougall, 2000: Decadal changes along an Indian Ocean section at $32^{\circ} \mathrm{S}$ and their interpretation. J. Phys. Oceanogr., 30, 1207-1222.

Broecker, W. S., and T.-H. Peng, 1982: Tracers in the Sea. LamontDoherty Geological Observatory of Columbia University Press, $690 \mathrm{pp}$.

Cushman-Roisin, B., 1987: Subduction. The Dymanics of the Oceanic Surface Mixed Layer: Proc. 'Aha Huliko' a Hawaiian Winter 
Workshop, Honolulu, HI, University of Hawaii at Manoa, 181196.

da Silva, A. M., C. C. Young, and S. Levitus, 1994a: Anomalies of Heat and Momentum Fluxes. Vol 3, Atlas of Surface Marine Data 1994, NOAA Atlas NESDIS 8, 411 pp.

, — a a , 1994b: Anomalies of Freshwater Fluxes. Vol. 4, Atlas of Surface Marine Data 1994, NOAA Atlas NESDIS 9, $308 \mathrm{pp}$.

England, M. H., J. S. Godfrey, A. C. Hirst, and M. Tomczak, 1993: The mechanism for Antarctic Intermediate Water renewal in a world ocean model. J. Phys. Oceanogr., 23, 1553-1560.

Fine, R. A., 1993: Circulation of Antarctic Intermediate Water in the South Indian Ocean. Deep-Sea Res., 40, 2021-2042.

Garabato, A. C. N., J. T. Allen, H. Leach, V. H. Strass, and R. T. Pollard, 2001: Mesoscale subduction at the Antarctic Polar Front driven by baroclinic instability. J. Phys. Oceanogr., 31, 20872107

Gill, A. E., 1982: Atmosphere-Ocean Dynamics. Academic Press, $662 \mathrm{pp}$.

Gordon, A. L., 1981: South Atlantic thermocline ventilation. DeepSea Res., 28, 1239-1264.

Gu, D., and G. Philander, 1997: Interdecadal climate fluctuations that depend on exchange between the tropics and the extratropics. Science, 275, 805-807.

Hanawa, K., and L. D. Talley, 2001: Mode waters. Ocean Circulation and Climate, G. Siedler, J. Church, and J. Gould, Eds., Academic Press, 373-386.

Hellerman, S., and M. Rosenstein, 1983: Normal monthly wind stress over the world ocean with error estimates. J. Phys. Oceanogr., 13, 1093-1104.

Huang, R. X., and B. Qiu, 1994: Three-dimensional structure of the wind-driven circulation in the subtropical North Pacific. J. Phys. Oceanogr., 24, 1608-1622.

- and - 1998: The structure of the wind-driven circulation in the subtropical South Pacific Ocean. J. Phys. Oceanogr., 28, $1173-1186$.

Iselin, C. O., 1939: The influence of vertical and lateral turbulence on the characteristics of the waters at mid-depth. Trans. Amer. Geophys. Union, 20, 414-417.

Jenkins, W. J., 1987: ${ }^{3} \mathrm{H}$ and ${ }^{3} \mathrm{He}$ in the beta triangle: Observations of gyre ventilation and oxygen utilization rates. J. Phys. Oceanogr., 17, 763-783.

Johnson, G. C., and A. H. Orsi, 1997: Southwest Pacific Ocean water mass changes between 1968/69 and 1990/91? J. Climate, 10, 306-316.

_ and M. McPhaden, 1999: Interior pycnocline flow from the subtropical to the equatorial Pacific Ocean. J. Phys. Oceanogr. 29, 3073-3089.

Josey, S. A., 2001: A comparison of ECMWF, NCEP-NCAR, and SOC surface heat fluxes with moored buoy measurements in the subduction region of the northeast Atlantic. J. Climate, 14, $1780-1789$.

_ F. C. Kent, and P. K. Taylor, 1999: New insights into the ocean heat budget closure problem from analysis of the SOC air-sea flux climatology. J. Climate, 12, 2856-2880.

$[, \ldots$, and $—, 2002$ : Wind stress forcing of the ocean in the SOC climatology: Comparisons with the NCEP-NCAR, ECMWF, UWM/COADS, and Hellerman and Rosenstein datasets. J. Phys. Oceanogr., 32, 1993-2019.

Karstensen, J., and M. Tomczak, 1998: Age determination of mixed water masses using CFC and oxygen data. J. Geophys. Res., 103, 18 599-18 610.

- and D. Quadfasel, 2002: Water subducted into the Indian Ocean subtropical gyre. Deep-Sea Res., 49, 1441-1457.

Kistler, R., and Coauthors, 2001: The NCEP-NCAR 50-Year Reanalysis: Monthly means CD-ROM and documentation. Bull. Amer. Meteor. Soc., 82, 247-268.

Levitus, S., and T. P. Boyer, 1994: Temperature. Vol. 4, World Ocean Atlas 1994, NOAA Atlas NESDIS 4, 117 pp.
R. Burgett, and T. P. Boyer, 1994: Salinity. Vol. 3, World Ocean Atlas 1994, NOAA Atlas NESDIS 3, 99 pp.

— , J. I. Antonov, T. P. Boyer, and C. Stephens, 2000: Warming of the world ocean. Science, 287, 2225-2229.

Luyten, J., J. Pedlosky, and H. Stommel, 1983: The ventilated thermocline. J. Phys. Oceanogr., 13, 292-309.

Marsh, R., J. G. Nurser, A. P. Megann, and A. L. New, 2000: Water mass transformation in the Southern Ocean of a global isopycnal coordinate GCM. J. Phys. Oceanogr., 30, 1013-1045.

Marshall, D., 1997: Subduction of water masses into an eddying ocean. J. Mar. Res., 55, 201-222.

Marshall, J. C., A. J. G. Nurser, and R. G. Williams, 1993: Inferring the subduction rate and period over the North Atlantic. J. Phys. Oceanogr., 23, 1315-1329.

—_ D. Jamous, and J. Nilsson, 1999: Reconciling thermodynamic and dynamic methods of computation of water-mass transformation. Deep-Sea Res., 46, 545-572.

Masuzawa, J., 1969: Subtropical Mode Water. Deep-Sea Res., 16, 463-472.

McCartney, M. S., 1977: Subantarctic Mode Water. A Voyage of Discovery: George Deacon 70th Anniversary Volume, M. Angel, Ed., Pergamon, 103-119.

- 1982: The subtropical recirculation of mode waters. J. Mar. Res., 40, 427-464.

Mémery, L., M. Arhan, X. A. A. Salgado, M. J. Messias, H. Mercier, C. G. Castro, and A. F. Rios, 1996: The water masses along the western boundary of the South and equatorial Atlantic. Progress in Oceanography, Vol. 47, Pergamon, 69-98.

Montgomery, R. B., 1938: Circulation in the upper layers of the southern North Atlantic deduced with use of isentropic analysis. Pap. Phys. Oceanogr. Meteor., 6, 55 pp.

Moyer, K. A., and R. A. Weller, 1997: Observations of surface forcing from the subduction experiment: A comparison with global model products and climatological datasets. J. Climate, 10, 27252742.

Nurser, A. J. G., and J. Marshall, 1991: On the relationship between subduction rates and diabatic forcing of the mixed layer. J. Phys. Oceanogr., 21, 1793-1802.

Orsi, A. H., T. W. Whitworth III, and W. D. Nowlin Jr., 1995: On the meridional extent and fronts of the Antarctic Circumpolar Current. Deep-Sea Res., 42, 641-673.

Provost, C., C. Escoffier, K. Maamaatuaiahutapu, A. Kartavtseff, and V. Garcon, 1999: Subtropical Mode Waters in the South Atlantic Ocean. J. Geophys. Res., 104, 21 033-21 049.

Qiu, B., and R. X. Huang, 1995: Ventilation of the North Atlantic and North Pacific: Subduction versus obduction. J. Phys. Oceanogr., 25, 2374-2390.

Reynolds, R. W., and T. M. Smith, 1995: A high-resolution global sea surface temperature climatology. J. Climate, 8, 1571-1583.

Ribbe, J., and M. Tomczak, 1997: On convection and the formation of Subantarctic Mode Water in the Fine Resolution Antarctic Model (FRAM). J. Mar. Syst., 13, 137-154.

Schmitt, R. W., P. S. Bogden, and C. E. Dorman, 1989: Evaporation minus precipitation and density fluxes for the North Atlantic. $J$. Phys. Oceanogr., 19, 1208-1221.

Schmitz, W. R., Jr., 1996: On the world ocean circulation: Vol. II. Tech. Rep. WHOI-96-08, Woods Hole Oceanographic Institution, $237 \mathrm{pp}$

Shaffer, G., O. Leth, O. Ulloa, J. Bendtsen, G. Daneri, V. Dellarossa, S. Hormazabal, and P.-I. Sehlstedt, 2000: Warming and circulation changes in the eastern South Pacific. Geophys. Res. Lett., 27, 1247-1250.

Sloyan, B. M., and S. R. Rintoul, 2001a: Circulation, renewal, and modification of Antarctic Mode and Intermediate Water. J. Phys. Oceanogr., 31, 1005-1031.

—_ and — 2001b: The Southern Ocean limb of the global deep overturning circulation. J. Phys. Oceanogr., 31, 143-173.

Speer, K., 1997: A note on average cross-isopycnal mixing in the North Atlantic Ocean. Deep-Sea Res., 44, 1981-1990. 
and E. Tziperman, 1992: Rates of water mass formation in the North Atlantic Ocean. J. Phys. Oceanogr., 22, 93-104.

— , H.-J. Isemer, and A. Biastoch, 1995: Water mass formation from revised COADS data. J. Phys. Oceanogr., 25, 2444-2457.

__ S. R. Rintoul, and B. M. Sloyan, 1997: Subantartic Mode Water formation by air-sea fluxes. International WOCE Newsletter, No. 29, WOCE International Project Office, Southampton, United Kingdom, 29-31.

—_ - and - 2000: The diabatic Deacon cell. J. Phys. Oceanogr., 30, 3212-3222.

Stommel, H., 1979: Determination of watermass properties of water pumped down from the Ekman layer to the geostrophic flow below. Proc. Natl. Acad. Sci. USA, 76, 3051-3055.

Stramma, L., 1992: The South Indian Ocean Current. J. Phys. Oceanogr., 22, 412-430.

— Oceanogr., 20, 846-859.

—_, and M. England, 1999: On the water masses and mean circulation of the South Atlantic Ocean. J. Geophys. Res., 104, $20863-20883$.

—_ R. G. Peterson, and M. Tomczak, 1995: The South Pacific Current. J. Phys. Oceanogr., 25, 77-91.

Sverdrup, H. U., M. W. Johnson, and R. H. Fleming, 1942: The Oceans: Their Physics, Chemistry, and General Biology. Prentice-Hall, 1087 pp.

Talley, L. D., 1999: Some aspects of ocean heat transport by shallow, intermediate and deep overturning circulations. Mechanisms of Global Climate Change at Millennial Time Scales, Geophys. Monogr., No. 112, Amer. Geophys. Union, 1-22.

Tandon, A., and C. Garrett, 1996: On a recent parameterization of mesoscale eddies. J. Phys. Oceanogr., 26, 406-416.
Tomczak, M., and S. Godfrey, 1994: Regional Oceanography: An Introduction. Pergamon, $422 \mathrm{pp}$.

Tsuchiya, M., and L. Talley, 1996: Water-property distribution along an eastern Pacific hydrographic section at 135W. J. Mar. Res. 54, 541-564.

Tziperman, E., 1986: On the role of interior mixing and air-sea fluxes in determining the stratification and circulation of the oceans. $J$. Phys. Oceanogr., 16, 680-693.

Walin, G., 1982: On the relation between sea-surface heat flow and thermal circulation in the ocean. Tellus, 34, 187-194.

Walker, S. J., R. F. Weiss, and P. K. Salameh, 2000: Reconstructed histories of the annual mean atmospheric mole fractions for the halocarbons CFC-11, CFC-12, CFC-113 and carbon tetrachloride. J. Geophys. Res., 105, 14 285-14 296.

Warner, M. J., and R. F. Weiss, 1985: Solubilities of chlorofluorocarbons 11 and 12 in water and seawater. Deep-Sea Res., 32, $1485-1497$.

Williams, R. G., 1991: The role of the mixed layer in setting the potential vorticity of the main thermocline. J. Phys. Oceanogr., 21, 1802-1814.

_ M. A. Spall, and J. C. Marshall, 1995: Does Stommel's mixed layer "demon" work? J. Phys. Oceanogr., 25, 3089-3102.

Wong, A. P. S., N. L. Bindoff, and J. A. Church, 1999: Large scale freshening of intermediate waters in the Pacific and Indian Oceans. Nature, 400, 440-443.

Woods, J. D., 1985: Physics of thermocline ventilation. Coupled Ocean-Atmosphere Models, J. C. J. Nihoul, Ed., Elsevier, 543590.

Zhang, H.-M., and L. D. Talley, 1998: Heat and buoyancy budgets and mixing rates in the upper thermocline of the Indian and Global Oceans. J. Phys. Oceanogr., 28, 1961-1978. 